\title{
Risks of seasonal extreme rainfall events in Bangladesh under 1.5 and 2.0 degrees' warmer worlds - How anthropogenic aerosols change the story
} Ruksana H. Rimi ${ }^{1}$, Karsten Haustein ${ }^{1}$, Emily J. Barbour ${ }^{1,2}$, Sarah N. Sparrow ${ }^{3}$, Sihan Li ${ }^{1,3}$, David C.H. Wallom $^{3}$ and Myles R. Allen ${ }^{1}$

$5 \quad{ }^{1}$ Environmental Change Institute, School of Geography and the Environment, University of Oxford, Oxford, OX1 3QY, UK. ${ }^{2}$ Commonwealth Scientific and Industrial Research Organisation, Land and Water, Canberra, ACT 2601, Australia.

${ }^{3}$ Oxford e-Research Centre, Department of Engineering Science, University of Oxford, Oxford, OX1 3QG, UK. 10

Correspondence: Ruksana H. Rimi (ruksana.rimi@ouce.ox.ac.uk) and Karsten Haustein (karsten.hausten@ouce.ox.ac.uk)

\begin{abstract}
Anthropogenic climate change is likely to increase the frequency of extreme weather events in future. Previous studies have robustly shown how and where climate change has already changed the risks of weather extremes. However, developing countries have been somewhat underrepresented in these studies, despite high vulnerability and limited capacities to adapt. How additional global warming would affect the future risks of extreme rainfall events in Bangladesh needs to be addressed to limit adverse impacts. Our study focuses on understanding and quantifying the relative risks of seasonal extreme rainfall events in Bangladesh under the Paris Agreement temperature goals of $1.5^{\circ} \mathrm{C}$ and $2{ }^{\circ} \mathrm{C}$ warming above pre-industrial levels. In particular, we investigate the influence of anthropogenic aerosols on these risks given their likely future reduction and resulting amplification of global warming. Using large ensemble regional climate model simulations from weather@home under different forcing scenarios, we compare the risks of rainfall events under pre-industrial (natural), current (actual), $1.5^{\circ} \mathrm{C}$, and $2.0^{\circ} \mathrm{C}$ warmer and greenhouse gas only (anthropogenic aerosols removed) conditions. We find that the risk of a 1 in 100 year rainfall event has already increased significantly compared with pre-industrial levels across parts of Bangladesh, with additional increases likely for 1.5 and 2.0 degree warming (of up to 5.5 times higher, with an uncertainty range of 3.5 to 7.8 times). Impacts were observed during both the pre-monsoon and monsoon periods, but were spatially variable across the country in terms of the level of impact. Results also show that reduction in anthropogenic aerosols plays an important role in determining the overall future climate change impacts; by exacerbating the effects of GHG induced global warming and thereby increasing the rainfall intensity. We highlight that the net aerosol effect varies from region to region within Bangladesh, which leads to different outcomes of aerosol reduction on extreme rainfall statistics, and must therefore be considered in future risk assessments. Whilst there is a substantial reduction in the impacts resulting from $1.5^{\circ} \mathrm{C}$ compared with $2^{\circ} \mathrm{C}$ warming, the difference is spatially and temporally variable, specifically with respect to seasonal extreme rainfall events.
\end{abstract}

30

\section{Introduction}

The 2015 Paris Agreement of the United Nations Framework Convention on Climate Change (UNFCCC), on "Holding the increase in the global average temperature to well below $2^{\circ} \mathrm{C}$ above pre-industrial levels and to pursue efforts to limit the temperature increase to $1.5^{\circ} \mathrm{C}$ " (Department of the Environment and Energy, 2015), needs strong support from research on the nature, benefits and feasibility of this challenging goal. This Agreement calls for the quantification and comparison between the impacts of $1.5^{\circ} \mathrm{C}$ versus $2.0^{\circ} \mathrm{C}$ warmer global temperatures on different climate related aspects such as extreme weather events. While assessing both risks and vulnerabilities to incremental increases in global mean temperature, the discrimination of the impacts of different radiative forcing contributions as well as the quantification of spatially varying changes in risk are crucially important. For example, highly unusual heat extremes that are virtually absent in the present climate in South Asia, would affect around $15 \%$ of land area of this region under $1.5^{\circ} \mathrm{C}$ and around $20 \%$ of land area under $2^{\circ} \mathrm{C}$ warming (The World Bank, 2012). The increase in heavy monsoon rainfall intensity for South Asia is projected to be $7 \%$ under $1.5^{\circ} \mathrm{C}$ and $10 \%$ under $2^{\circ} \mathrm{C}$ warming compared to pre-industrial conditions (Schleussner et al., 2016). Populations of this region largely depend on the stability of the monsoon, which provides water resources for agricultural production (The World Bank, 2012). It is 
projected that the years with above-normal monsoon rainfall will be more frequent (Endo et al., 2013; Kripalani et al., 2007). The seasonality of rainfall will be amplified with more rainfall during the wet season (Fung et al., 2011; Turner and Annamalai, 2012), and finally also the number of extreme rainfall events is projected to increase (Endo et al., 2012; Kumar et al., 2011; Vinke et al., 2017). Here we assess whether these generalized projections are also valid using a large ensemble regional climate model

5 framework focusing on Bangladesh.

Bangladesh is potentially a hotspot of climate change impacts as it is vulnerable to a combination of increasing challenges from record-breaking temperatures, extreme rainfall events, more intense river floods, tropical cyclones, and rising sea levels (The World Bank, 2012). Bangladesh has a tropical monsoon climate, flat and low-lying topography, and unique geographical location in the Ganges-Brahmaputra-Meghna Basin (Rawlani and Sovacool, 2011; Banglapedia, 2012). For these features, heavy rainfall events in the pre-monsoon and monsoon seasons are associated with a high risk of flooding and landslides almost every year. In recent years, the frequency of high-intensity rainfall events has shown an increasing trend in the observations (Murshed et al., 2011). For example, in 2017, heavy rainfall across the upstream Meghalaya hills in India and in Bangladesh caused premonsoon floods in March in the northeastern parts of the country. Consequently, vast areas of Haors (local names for lowland wetlands) and low-lying areas were inundated and damaged nearly harvestable Boro (a local high yielding variety of rice) paddy crops (Nirapad, 2017). In June 2017, heavy rain induced floods and landslides killed at least 156 people. National Aeronautics and Space Administration (NASA) reported the heaviest rainfall accumulation of more than $510 \mathrm{~mm}$ in 3 days (12-14 June 2017) in southeastern Bangladesh (Gutro, 2017).

20 Considering the unfolding change in risk of heavy rain in the region under present day conditions how would a $1.5^{\circ} \mathrm{C}$ and a $2.0^{\circ} \mathrm{C}$ warmer world change the probability of extreme rainfall events in Bangladesh? If climate change is already playing a role, then similar events are likely to occur even more frequently as global warming continues in the future (Faust, 2017). Reliable information regarding the relative changes in future risks of extreme rainfall events can help to provide local decision makers to address the problem, develop appropriate adaptation strategies and allocate resources to minimize loss and damage associated with climate. A multi global climate model (GCM) ensemble based study conducted for northwestern part of Bangladesh reported $\sim 9 \%$ and $\sim 18 \%$ increase in mean seasonal rainfall during pre-monsoon (Mar-May) and monsoon (Jun-Sep) seasons respectively by 2090 (Kumar et al., 2014). Caesar et al., (2015) used high resolution (25 km) regional climate model, HadRM3P that is nested in global HadCM3 model and projected a large increase in the very heavy daily rainfall events ( $>99$ th percentile, i.e., $>23.8 \mathrm{~mm} /$ day) and a decrease in the light-moderate rainfall events ( $<75$ th percentile, i.e., $<12.3 \mathrm{~mm} /$ day) during monsoon season

30 (Jun-Sep) over Bangladesh by 2099. According to PRECIS (Providing REgional Climates for Impact Studies) model projection for 2080, the north-east parts of Bangladesh would experience up to $75 \%$ more pre-monsoon rainfall compared to the baseline of 1971-2000 (Nowreen et al., 2015). While previous studies projected future changes in the seasonal mean or extreme rainfall events over a specific part or the whole of Bangladesh; none had the benefit of using very large model ensembles of high resolution regional climate models to examine exceptionally rare extreme rainfall events (e.g., events with 100-1000 year of return periods); explained whether or not anthropogenic climate change played a role in those projected future rainfall events; and explored how anthropogenic aerosols changed the overall climate change impacts on rainfall events. The Fifth Phase Coupled Model Inter-comparison Project (CMIP5) models produced a broad range of temperature projections as a function of model sensitivity (van Vuuren et al., 2011). However, the specified warming targets set in the Paris Agreement were not addressed in those experiments. Hence the Half a degree additional warming, prognosis and projected impacts (HAPPI) framework has been developed, specifically targeted for $1.5^{\circ} \mathrm{C}$ and $2.0^{\circ} \mathrm{C}$ warming (Mitchell et al., 2015). There are only a few studies using CMIP5 (e.g., Fahad et al., 2017), or PRECIS ( e.g., Nowreen et al., 2015) runs that investigated future changes in the rainfall events over Bangladesh, but none of these have specifically addressed the warming targets of the Paris Agreement. The novelty of this study lies in meeting all these aforementioned challenges. 

and microphysical effects (Guo et al., 2013; Li et al., 2016), but also because extreme rainfall events have higher sensitivity to

5 aerosol removal per degree of surface warming, in particular over the major aerosol emission regions like Asia (Samset et al., 2018). Therefore it is important to explore aerosol impacts while assessing the changes in the risks of extreme rainfall events under additional global warming scenarios of 1.5 and 2.0 degrees' according to the Paris Agreement.

Drawing on the large ensemble of regional climate model (RCM) runs generated with the weather@home system (Guillod et al., 2017; Massey et al., 2015) within the HAPPI experimental framework, here we quantify changing rainfall risks for Bangladesh during pre-monsoon (Mar-May; MAM) and monsoon (Jun-Sep; JJAS) seasons. In order to look at local sub-regional scale rainfall risks within Bangladesh, we use sub-regions 1-4 located at north-west $\left(88^{\circ}-90^{\circ} \mathrm{E}, 24^{\circ}-26^{\circ} \mathrm{N}\right)$, north-east $\left(90.5^{\circ}-92.5^{\circ} \mathrm{E}, 24^{\circ}\right.$ $\left.25.5^{\circ} \mathrm{N}\right)$, south-west $\left(89^{\circ}-91^{\circ} \mathrm{E}, 21.5^{\circ}-23.5^{\circ} \mathrm{N}\right)$ and south-east $\left(91^{\circ}-93^{\circ} \mathrm{E}, 20.5^{\circ}-24^{\circ} \mathrm{N}\right)$ respectively (for locations of the subregions, see boxes in Fig. 2e and 3e). The risk of extreme rainfall events is evaluated for current and future climate scenarios, a counterfactual 'natural' scenario as well as a current climate with no anthropogenic aerosols (GHG only) scenario. In particular, the impact of anthropogenic aerosol emissions is discussed and quantified.

We first introduce data and methods in Section 2, whilst a summary of model performance is presented in Section 2.2. Further details on model evaluation are provided in Rimi et al. (under review). We then assess percentage changes and standardized changes in the seasonal mean rainfall within five forcing scenarios (Natural, Actual, GHG only, $1.5^{\circ} \mathrm{C}$ and $2.0^{\circ} \mathrm{C}$ ). Finally, in Section 3.3 we explore the change in daily and five day mean rainfall during the pre-monsoon and monsoon seasons using return times over the four sub-regions, and identify the relative shifts in the probabilities of extreme rainfall events between the different forcing scenarios. The results are discussed in context of regional vulnerabilities and observed changes in Section 4 .

\section{Data and Methods}

\subsection{Observational data}

Two observational datasets are used to compare against model results, observational (i) Asian Precipitation Highly Resolved Observational Data Integration Towards Evaluation of Water Resources (APHRODITE) daily rainfall data for the duration of 1998-2007 (Yatagai et al., 2012) and (ii) NOAA's Climate Prediction Center (CPC) global $0.5^{\circ}$ analysis of daily rain gauge measurements covering 2006-2015 (Chen et al., 2008). APHRODITE is the only long-term continental-scale, daily gridded rainfall dataset (available for 1951-2007) with high-resolution grids for Asia; created primarily with data obtained from a raingauge-observation network. CPC global daily rainfall dataset (available from 1979 to present) is constructed through a unified analysis of gauge-based daily rainfall over global land (Chen and Xie, 2008). Basic facts about these two observation datasets are presented in the Table S1 in the supplementary information. APHRODITE and CPC were also used in the model evaluation conducted by (Rimi et al., under review). Both model and observation data are re-gridded using bi-linear interpolation method to have similar and comparable grid structures.

\subsection{Model setup and experimental design}

Weather@home is part of the climateprediction.net (Stainforth et al., 2005) program and is able to generate very large ensembles 
Asia region) that is nested in the global atmosphere-only HadAM3P model of weather@home system and is driven by prescribed sea surface temperatures (SSTs) and radiative forcing (Massey et al. 2015; Guillod et al. 2017) to generate the model ensembles of present-day actual climate conditions (denoted as 'ACT'); the counterfactual world with natural climate conditions of preindustrial period with no anthropogenic warming influences (denoted as 'NAT'); and the hypothetical world with the greenhouse gas (GHG) only climate condition where the anthropogenic aerosols are reduced to pre-industrial levels (denoted as 'GHG') Evaluation of the model for the region was conducted by Rimi et al (under review), and demonstrated a reasonable agreement between model results and observational datasets for extreme rainfall events. In particular, the monsoon dynamics over the Indian subcontinent and adjacent regions is well reproduced in HadRM3P.

HAPPI experiments are designed to address the research questions relating to $1.5^{\circ} \mathrm{C}$ and $2.0^{\circ} \mathrm{C}$ warming, with weather@home's HadAM3P being one of the contributing models used to generate large climate ensembles (Massey et al., 2015; Otto, 2017; Stainforth et al., 2005). Following the experimental set up of the HAPPI framework (for details see Mitchell et al., 2017), this study uses experiments of three decadal model ensembles:

1. ACT model ensemble with 98 members per year representing the current decade (2006-2015) with actual climatic conditions, using observed SST data from the Operational Sea Surface Temperature and Sea Ice Analysis (OSTIA) dataset (Donlon et al., 2012; Stark et al., 2007) and present-day atmospheric GHG and aerosol concentration.

2. HAPPI 1.5 model ensemble (2091-2100) with 98 members per year representing $1.5^{\circ} \mathrm{C}$ warmer than pre-industrial (1861-1880) climatic conditions, and

3. HAPPI 2.0 model ensemble (2091-2100) with 98 members per year representing $2.0^{\circ} \mathrm{C}$ warmer than pre-industrial (1861-1880) climatic conditions.

For the HAPPI 1.5 model ensemble, the RCP 2.6 scenario is used to provide the model boundary conditions. In the RCP 2.6 scenario, the mean global temperature reaches to $\sim 1.55^{\circ} \mathrm{C}$ by 2100 (Mitchell et al., 2017). Since there is no analogous CMIP5 simulation available which results in $\sim 2^{\circ} \mathrm{C}$ warmer temperatures relative to preindustrial levels, a weighted combination of

RCP2.6 and RCP 4.5 is used to provide the model boundary conditions of SST and sea ice for the HAPPI 2.0 model ensemble. The global mean temperature response reaches to $\sim 2.05^{\circ} \mathrm{C}$ by the end of century in the HAPPI 2.0 model ensemble (Mitchell et al., 2017). Following the RCP2.6 protocol, anthropogenic aerosol concentrations are approximately 1/3th of the current levels (IPCC, 2013) in both HAPPI scenarios.

In addition, we use two model ensembles of hypothetical world climate conditions:

4. NAT model ensemble with 98 members per year representing the current decade (2006-2015) climatic conditions, but here the modelled SST patterns of anthropogenic forcing ( $\triangle \mathrm{SST}$ hereinafter) are removed (subtracted) from the observed SSTs to simulate a counterfactual world. $\triangle$ SSTs are generated from the CMIP5 archive (Schaller et al. 2016):

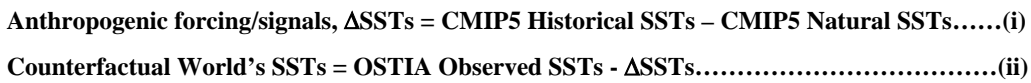

GHG and aerosol concentrations are set to pre-industrial levels.

5. GHG only model ensemble with 98 members per year representing the current decade (2006-2015) climatic conditions, but with anthropogenic aerosol concentrations reduced to pre-industrial levels to simulate a hypothetical climate, where impacts of aerosols are removed. The difference between ACT and GHG only conditions simulates the net aerosol effect under current conditions assuming additive behaviour of different radiative forces. The GHG only model ensemble with anthropogenic aerosols reduction scenario in the HadRM3P model is satisfactorily representative when compared with the other GCMs (Haustein et al., in progress). Based on the very limited sample of CMIP5 aerosol only (AA) experiments, we found that the resulting $\triangle \mathrm{SST}$ pattern are reasonably similar compared with $\triangle \mathrm{SST}$ s from ACT minus GHG only (not shown). 

return times of the daily and five day mean rainfall in pre-monsoon and monsoon seasons, we used 98 plausible model realizations with initial condition perturbations for the 10-year period within 2006-2015. For each year, three (MAM) or four (JJAS) months

5 of data are used. Therefore, we have $90 \times 10 \times 98=88,200$ simulated values to calculate the return periods of pre-monsoon rainfall events. For the monsoon season, we have 120x10x98 = 117,600 simulated values to calculate the return periods. Such large sample size allows us to estimate a range of physically plausible climate conditions with focus on the tails of the distribution which can be robustly determined. To add a qualitative representation of the year to year natural variability from the present day actual climate simulated in the ACT model ensemble, we use two of the wettest and two of the driest years during the decade of 2006-2015 (the spatiotemporal average for the corresponding sub-region and season over the 10-year simulation period has been used to determine the wettest and driest year; see also Table S2). By comparing these two subsampled model ensembles with the ensembles of different forcing scenarios, we can estimate the signal-to-noise ratio in the return period plots. The supplementary material of Table S2 lists the wettest and driest years for pre-monsoon and monsoon seasons over the four different sub-regions.

15 We presented the change in the occurrence probability of rainfall event, Risk Ratio (RR) (NAS, 2016) quantified as

$$
\boldsymbol{R} \boldsymbol{R}=\boldsymbol{P}_{\mathrm{f}} / \boldsymbol{P}_{\text {cf }}
$$

where probability of the event in the factual climate including climate change (ACT, HAPPI 1.5 and HAPPI 2.0 scenarios) is denoted by $\mathrm{P}_{\mathrm{f}}$, and the probability of the same event in a counterfactual climate without anthropogenic climate change (NAT scenario) is denoted by $\mathrm{P}_{\mathrm{cf}}$. An exception to this is the GHG only scenario, where RR is calculated using $\mathrm{P}_{\mathrm{cf}}=$ actual climate (ACT) instead of natural climate (NAT). We provided the changes in the RRs for four event thresholds in pre-monsoon and monsoon seasons with return period of 10, 20, 50 and 100 year over the four sub-regions of Bangladesh.

\section{Results and Discussion}

\subsection{Model Evaluation for Five Day Mean Rainfall}

To explore how pre-monsoon and monsoon rainfall is likely to change in Bangladesh over the four sub-regions, we investigate the annual cycle of five day mean rainfall under different forcing scenarios in comparison to observations. Five day mean rainfall is used to represent the timescale responsible for river flooding as opposed to daily extremes that cause flash floods primarily in the pre-monsoon season. In Figure 1, annual cycles of five day mean rainfall as in the simulations of model ensembles under five different forcing scenarios (ACT, NAT, GHG, HAPPI 1.5 and HAPPI 2.0) and two observations (APHRODITE and CPC) are shown. The coloured lines represent the ensemble means, with light-coloured shading representing the 10-90\% percentile ranges (only shown for ACT model ensemble and the observations).

The annual cycle of five day mean rainfall from the different model ensembles are adequately representative of the observed annual cycle. However, the monsoon rainfall during JJAS months is underestimated by $25-65 \%$ depending on the observational dataset it is compared with and sub-regions. The monsoon rainfall bias is higher (35-65\% dry bias) at the wetter sub-regions of 2 and 4 (see Figs. 1b \& d) and lower (25-50\% dry bias) at the drier sub-regions of 1 and 3 (see Figs. 1a \& c). We note that the bias is present in all model scenarios; hence it is unlikely to affect the comparison between model scenarios. We also note that the signal of the change due to the changing climate is relatively small in comparison to the total rainfall. More details regarding the model's performance over the four sub-regions of Bangladesh can be found in Rimi et al. 2018 (under review). The differences between the forcing scenarios throughout the annual rainfall cycle are discussed below. 


\subsection{Impact of Climate Change and Aerosol Reduction on Seasonal Mean Rainfall}

Our results suggest that changes in mean rainfall due to global warming are significant for both the pre-monsoon and monsoon periods, and that aerosols play an important role in determining the magnitude of future changes (Fig. 2 and Fig. 3). These changes are particularly evident in the pre-monsoon season based on percentage change (PC), yet a smaller PC during the

5 monsoon season can still have a significant impact given the magnitude of rainfall. Relative changes between pairs of forcing scenarios show large spatial variability over Bangladesh and the wider central South Asia region, although suggest a general wetting trend across Bangladesh for both $1.5^{\circ} \mathrm{C}$ and $2.0^{\circ} \mathrm{C}$ degree warmer worlds.

During the pre-monsoon season (Fig. 2), results show a non-linear response to temperature change in the PC over the eastern part

10 of South Asia (see Figs. 2 a, b, \& c) that is likely to be caused at least in part by the response for aerosols in the Fig.2 d. The present day (ACT) PC relative to the pre-industrial period (NAT) indicates that the mean pre-monsoon rainfall is reduced by 15 $30 \%$ over the eastern parts of South Asia and increased by 15-25\% over the northern parts Bangladesh (Fig. 2a). Figure 2d shows the spatial distribution of the "omitted" aerosol induced rainfall over the South Asia region. Once aerosol levels drop to 1/3th of its current values (following the RCP2.6 protocol, IPCC, 2013), an increase of up to $20 \%$ in the pre-monsoon rainfall is very likely to happen over most parts of South Asian region. Associated with this increased rainfall, the PC relative to present day (ACT) in a $1.5^{\circ} \mathrm{C}$ warmer world (HAPPI 1.5) increases up to $20 \%$ over South Asia (Fig. 2b), with Bangladesh being the region where the aerosol effect dominates the total change (Fig. $2 \mathrm{f} \& 2 \mathrm{~h}$ ).

Across Bangladesh, our results indicate that the pre-monsoon rainfall increases approximately linearly with temperature, suggesting a primary role for thermodynamic effects and only a secondary role for dynamic changes as far as our HadRM3P model results are concerned. The additional warming effects in a $2.0^{\circ} \mathrm{C}$ world (HAPPI 2.0) increase the mean pre-monsoon rainfall by an extra 10-20\% over Bangladesh (Fig. 2g), in contrast to other parts of Asia. Using other RCM projections (based on RCP8.5), Fahad et al. (2017) pointed out that pre-monsoon seasonal mean rainfall may significantly increase by up to $20 \%$ relative to their baseline period (1971-2000) over the eastern mountainous region of Bangladesh, in line with our results for 1.5 and $2.0^{\circ} \mathrm{C}$ warming. However, the fact that the northern parts of India show very non-linear behaviour with regard to rainfall PC in response to the combined GHG and aerosol-related radiative forcing (see Fig. 2a-2d) is indicative of circulatory, dynamic shifts with stronger warming. This is opposed to a more linear thermodynamic response which usually scales with $20-40 \%$ of ClausiusClapeyron for non-extreme rainfall.

30 The PC of mean monsoon seasonal rainfall in the present-day climate (ACT) relative to pre-industrial period (NAT) (Fig. 3a) indicates a weakening monsoon over central India and strengthening of the monsoon over Bangladesh and north-east India (10$15 \%$ increase in mean monsoon seasonal rainfall). Evidence for reduced monsoon rainfall amounts over the last few decades in the South Asian region is also found in the observational record (Bollasina et al., 2011; Srivastava et al., 2010; Turner and Annamalai, 2012; Wang et al., 2012). In contrast, the CMIP5 models simulate about $2.3 \%$ increase in rainfall per degree of warming for the Indian summer monsoon (Menon et al., 2013) due to an increase in moisture availability in a warmer world. These conflicting results can be attributed to an underestimated aerosol effect in many CMIP5 models. Subsampling those models that include indirect aerosol effects helps to resolve the discrepancy (Bollasina et al., 2011; Turner and Annamalai, 2012). We highlight that the HadRM3P model estimates the aerosol effects satisfactorily (Haustein et al., in progress); besides the results are largely consistent with observed rainfall trends.

40

The most significant change in the PC occurs in the $1.5^{\circ} \mathrm{C}$ warmer world relative to the current actual world (Fig. 3b). Comparing HAPPI 1.5 and $2.0^{\circ} \mathrm{C}$, we find an additional increase in the mean monsoon rainfall but of lower magnitude (a further 10 to $20 \%$ 
increase; Fig. 3c). Comparing NAT to ACT, we find a very strong drying tendency during JJAS conceivably due to the presence of anthropogenic aerosols over most parts of South Asia (Fig. 3a). Correspondingly, the "committed" rainfall increase, which will be realised once aerosol emissions are reduced (Fig. 3d), is in the order of 15-30\%. This means that the observed drying is likely to be caused by the aerosols that have overcompensated, and hence efficiently masked, the GHG induced rainfall increase. In

5 Bangladesh (see Figs 3e-3h), the aerosol effect is less strong and GHG induced intensification of summer monsoon rainfalls have already increased the risk of more intense rain. The SPI index analysis for the pre-monsoon and monsoon seasons (see Figs. S1 \& $\mathrm{S} 2$ in the supplementary information) corroborates our results from the PC analysis.

In addition to PC and SPI that are relative analyses of rainfall amounts, we looked at the absolute rainfall over the four subregions in Bangladesh (Fig. 4 \& 5) for each of the five forcing scenarios during MAM and JJAS, to explain the variability of mean absolute rainfall (median, as well as the $25-75^{\text {th }}$ percentiles of seasonal mean rainfall) across the scenarios. Changes in the mean absolute rainfall are much more pronounced over sub-region 1 and 2 during pre-monsoon season (see Fig. 4 a \& c), whereas smaller absolute changes occur in sub-region 3 and 4 during monsoon season only (Fig. 5 b \& d). The absolute aerosol effect is strongest in the monsoon, yet the relative change is smaller which is in line with lower rainfall PC as discussed above. Most importantly, however, aerosols play a dominant role in all sub-regions and seasons (except in the pre-monsoon for sub-regions 3 and 4; see Fig. 5 a \& c). Despite more effective aerosol removal from the atmosphere by means of wet deposition during the monsoon season, high regional emission rates prevent drastic reductions of the aerosol optical depth. As a result, direct and indirect aerosol effects, accompanied by feedbacks such as reduced lapse rate, increased atmospheric stability, or a modified landsea circulation, remain to be an important driver for changing monsoonal rainfall amounts.

For future warming scenarios (HAPPI 1.5 and HAPPI 2.0) compared to current actual climate conditions (ACT), we find linear (absolute) increase in rainfall in all sub-regions and seasons. Conversely, we find no clear trend between NAT, ACT and HAPPI 1.5 in MAM in sub-region 3 and 4 (Fig. 5 a \& c). While aerosol effects are consistent with other regions, the GHG induced rainfall is hampered, likely due to dynamic changes such as a delayed onset of the monsoon in response to warming. The proximity to the Indian Ocean may also be a contributing factor. While the atmosphere can hold more moisture, the slower ocean warming stabilises the atmosphere over sea in the same way aerosols stabilise the atmosphere over land.

As shown in Fig. 1, the monsoon onset in sub-region 3 and 4 (Fig. 1 c \& d) does not change notably under different forcing scenarios as far as 5 day mean rainfall is concerned. Otherwise, the aerosol and GHG induced response is consistent with the conclusions based on the spatial maps across the four sub-regions. Sub-regions 1 and 2 show considerable changes in rainfal strength during the pre-monsoon season, with an earlier onset in the HAPPI 2.0 scenario in sub-region 2. The most pronounced change is simulated during the peak of the monsoon in early June in sub-region 2, with an associated increase in magnitude of almost 1/3 between NAT and HAPPI 2.0. It is noteworthy that this increase in rainfall appears to be robustly linear with progressively warmer climate conditions (see Fig. 1b).

35

\subsection{Extreme Rainfall Events}

Bangladesh is likely to experience significantly higher frequencies of occurrence for 1 and 5 day extreme rainfall events during pre-monsoon and monsoon seasons over sub-regions 1 and 2 for a $1.5^{\circ} \mathrm{C}$ change (Figs. 6-9 and S3-S6, respectively). Whereas, changes between HAPPI 1.5 and HAPPI 2.0 are only significant in sub-regions 1 and 2 in monsoon season (Fig. 8 a \& b). The signal-to-noise ratio is higher in the monsoon season across all sub-regions with the lowest and highest ratio in sub-region 1 and 3 , respectively (Figs. 8a \& 9a). In summary, the most linear rainfall response to warming is simulated in sub-region 2 in MAM and JJAS (Figs. 6b \& 8b); with aerosols masking approximately 50\% of the increased risk with regard to 1-in-100-year NAT return 
time (see Fig. 8d; return period of $\sim 70$ years in actual climate is $\sim 35$ years in GHG only climate). Hence future rainfall in subregion 2 is continuing to increase, with accelerated pace once aerosol levels drop significantly. We find the same result over subregion 1 , which is likely to receive more extreme rainfall as well with continued warming, with strong increases once aerosol levels drop. In both regions, dynamic feedback processes appear to counter the thermodynamic increase in rainfall risk with continued warming.

Figures 10 and 11 illustrate changes in risk ratios. These changes vary seasonally and spatially. Supplementary material of Table S3 presents the risk ratios with associated uncertainty ranges for both seasons over four sub-regions. Here we summarize the risk ratios in order of the four sub-regions. The present day risk for rainfall events in pre-monsoon season over sub-region 1 has not changed (Fig. 10a; see RR for ACT/NAT); but the risk of extreme rainfall event with respect to 1-in-100-year NAT return time increase by a factor of 4 (with uncertainty range 2.0-7.0) in a $1.5^{\circ} \mathrm{C}$ world (Fig. 10a; see RR for HAPP1.5/NAT). Over the subregion 2, the risk of extreme monsoon rainfall event with respect to 1-in-100-year NAT return time increases 3-fold (with uncertainty range 1-4) in a $1.5^{\circ} \mathrm{C}$ world and then 4.6 -fold (with uncertainty range $2.9-7.2$ ) in a $2.0^{\circ} \mathrm{C}$ world (Fig. 10d). The risk of a 1 in 100 year pre-monsoon rainfall event over Sub-region 3, which has not changed much from the natural world to actual world; increases 2-fold (with uncertainty range 1.0-3.0) and 3.1-fold (with uncertainty range $1.9-5.2$ ) in a $1.5^{\circ} \mathrm{C}$ and $2.0^{\circ} \mathrm{C}$ worlds respectively. Sub-region 4 (see Fig. 11d), where current risks of monsoon extreme rainfall are already increased 3.9 times (with uncertainty range 2.6-5.8) with respect to 1-in-100-year NAT return time; the risk for similar event increases 4.1 times (with uncertainty range $2.2-5.3$ ) in a $1.5^{\circ} \mathrm{C}$ world and 5.5 times in a $2.0^{\circ} \mathrm{C}$ world (with uncertainty range $3.5-7.8$ ). The aerosol impact is strongest over sub-region 1 in pre-monsoon season (in Fig. 10, compare RR for GHG/ACT between a \& c) compared the monsoon seasons.

\section{Conclusions}

Results of the weather@home HadRM3P South Asia regional model suggest that both a $1.5^{\circ} \mathrm{C}$ and $2.0^{\circ} \mathrm{C}$ warming are projected to increase seasonal mean and to a lesser extent the extreme rainfall during the pre-monsoon and monsoon seasons across

Bangladesh. These increases are likely to be amplified by a reduction in aerosols, consistent with previous findings (Samset et al., 2018). These projected changes have important implications for agricultural yields and associated economic losses, particularly during the pre-monsoon season. In contrast, property damage is more likely to occur during the monsoon season when large inhabited areas are inundated on a regular basis. We find that there are large spatial variations in the patterns of changes in the relative risks of extreme rainfall in Bangladesh.

30

While there are substantial uncertainties in current and future changes in extreme rainfall risk, we conclude that the drier subregions show a greater masking effect from the aerosols during the pre-monsoon season; whereas, the wetter sub-regions have a smaller aerosol effect particularly during the monsoon season. This is in line with a growing array of research that has shown that anthropogenic aerosols play a substantial role in modulating the strength of the monsoon in South Asia (Bollasina et al., 2011, 2013; Lau and Kim, 2010; Ramanathan et al., 2005). As far as other regions in South Asia are concerned, our results imply that the present-day decline in the mean monsoon seasonal rainfall can be explained by the existing atmospheric aerosols impacts, which offsets the GHG-induced global warming effects. Future aerosol removal from the atmosphere will unmask the GHG induced rainfall increase with surprisingly fast changes in risk due to the non-linear nature of the imposed external forcing contributions (e.g., over sub-region 1 in pre-monsoon season, see Fig. 6c and Fig. S3c). For that reason we emphasize that the 

extreme rainfall into account, but also the non-linearity in the response. Relying on observed changes can be deeply misleading, creating an unwarranted sense of security. Our study highlights that preparedness for more frequent extremes is key in the northern part of Bangladesh during both the pre-monsoon and the monsoon season. The magnitude of change exceeds the current

5 internal year-to-year variability in the associated sub-regions 1 and 2 during MAM and JJAS. While additional regional model experiments are needed to confirm the weather@home model results, available data from other HAPPI GCMs point in the same direction (Lee et al., 2018). However, since they do not allow for a quantification of the aerosol effect, we call for more nuanced experiments in that regard in the future.

\section{Author contributions}

Ruksana H. Rimi's contribution towards this work was performed as part of her DPhil research project. All results were analysed and plotted by Ruksana H. Rimi with advice from Myles R. Allen, Karsten Haustein, and Emily Barbour. Sihan Li and Sarah N. Sparrow prepared and distributed the computational simulations to generate the data used in the study onto the weather@home system. David C.H. Wallom manages operation of the weather@home/climateprediction.net infrastructure which was used to generate the data. The paper was written by Ruksana H. Rimi, with edits from all co-authors.

\section{Acknowledgments}

We would like to thank the Met Office Hadley Centre PRECIS team for their technical and scientific support for the development and application of weather@ home. We acknowledge the use of the observation datasets of APHRODITE and CPC. Finally, we would like to thank all the volunteers who have donated their computing time to climateprediction.net and weather@home. The authors declare that they have no conflict of interest.

\section{References}

Allen, M.: Do-it-yourself climate prediction, Nature, 401(6754), 642, doi:10.1038/44266, 1999.

Bollasina, M. A., Ming, Y. and Ramaswamy, V.: Anthropogenic aerosols and the weakening of the south asian summer monsoon, Science (80-. )., 334(6055), 502-505, doi:10.1126/science.1204994, 2011.

Bollasina, M. A., Ming, Y. and Ramaswamy, V.: Earlier onset of the Indian monsoon in the late twentieth century: The role of anthropogenic aerosols, Geophys. Res. Lett., 40(14), 3715-3720, doi:10.1002/grl.50719, 2013.

Caesar, J., Janes, T., Lindsay, A. and Bhaskaran, B.: Temperature and precipitation projections over Bangladesh and the upstream Ganges, Brahmaputra and Meghna systems, Environ. Sci. Process. Impacts, 17(6), 1047-1056, doi:10.1039/C4EM00650J, 2015.

Chen, M. and Xie, P.: CPC Unified Gauge-based Analysis of Global Daily Precipiation, in Western Pacific Geophysics Meeting, Cairns, Australia, 29 July - 1 August, 2008, vol. 2, pp. 179-184. [online] Available from: ftp://ftp.cpc.ncep.noaa.gov/precip/CPC_UNI_PRCP/GAUGE_CONUS/DOCU/Chen_et_al_2008_Daily_Gauge_Anal.pdf, 2008.

Chen, M., Shi, W., Xie, P., Silva, V. B. S., Kousky, V. E., Higgins, R. W. and Janowiak, J. E.: Assessing objective techniques for gauge-based analyses of global daily precipitation, J. Geophys. Res. Atmos., 113(4), doi:10.1029/2007JD009132, 2008.

Department of the Environment and Energy: Paris Agreement, in Europa, vol. 2017, pp. 21-32. [online] Available from: https://unfccc.int/sites/default/files/english_paris_agreement.pdf, 2015.

Donlon, C. J., Martin, M., Stark, J., Roberts-Jones, J., Fiedler, E. and Wimmer, W.: The Operational Sea Surface Temperature and 
Sea Ice Analysis (OSTIA) system, Remote Sens. Environ., 116, 140-158, doi:10.1016/j.rse.2010.10.017, 2012.

Endo, H., Kitoh, A., Ose, T., Mizuta, R. and Kusunoki, S.: Erratum: Future changes and uncertainties in Asian precipitation simulated by multiphysics and multi-sea surface temperature ensemble experiments with high-resolution Meteorological Research Institute atmospheric general circulation models (MRI-AGCMs) (Jo, J. Geophys. Res. Atmos., 118(5), 2303,

5 doi:10.1002/jgrd.50267, 2013.

Fahad, M. G. R., Saiful Islam, A. K. M., Nazari, R., Alfi Hasan, M., Tarekul Islam, G. M. and Bala, S. K.: Regional changes of precipitation and temperature over Bangladesh using bias-corrected multi-model ensemble projections considering high-emission pathways, Int. J. Climatol., doi:10.1002/joc.5284, 2017.

Faust, E.: Rapid attribution: Is climate change involved in an extreme weather event?, [online] Available from:

10 https://www.munichre.com/topics-online/en/2017/topics-geo/rapid-attribution, 2017.

Fung, F., Lopez, A. and New, M.: Water availability in $+2 \mathrm{C}$ and $+4 \mathrm{C}$ worlds, Philos. Trans. R. Soc. A Math. Phys. Eng. Sci., 369(1934), 99-116, doi:10.1098/rsta.2010.0293, 2011.

Guillod, B. P., Jones, R. G., Bowery, A., Haustein, K., Massey, N. R., Mitchell, D. M., Otto, F. E. L., Sparrow, S. N., Uhe, P., Wallom, D. C. H., Wilson, S. and Allen, M. R.: Weather@home 2: Validation of an improved global-regional climate modelling system, Geosci. Model Dev., 10(5), 1849-1872, doi:10.5194/gmd-10-1849-2017, 2017.

Guo, L., Highwood, E. J., Shaffrey, L. C. and Turner, A. G.: The effect of regional changes in anthropogenic aerosols on rainfall of the East Asian Summer Monsoon, Atmos. Chem. Phys., 13(3), 1521-1534, doi:10.5194/acp-13-1521-2013, 2013.

Gutro, R.: Bangladesh's Heavy Rainfall Examined With NASA's IMERG, Nasa Gpm [online] Available from: https://www.nasa.gov/feature/goddard/2017/bangladeshs-heavy-rainfall-examined-with-nasas-imerg (Accessed 14 November 20 2017), 2017.

Hauser, M., Gudmundsson, L., Orth, R., Jézéquel, A., Haustein, K., Vautard, R., van Oldenborgh, G. J., Wilcox, L. and Seneviratne, S. I.: Methods and Model Dependency of Extreme Event Attribution: The 2015 European Drought, Earth's Futur., 5(10), doi:10.1002/2017EF000612, 2017.

Haustein, K., Uhe, P. F., Rimi, R. H., Islam, A. S. and Otto, F. E. L.: Is the wettest place on Earth getting wetter?, Geophys. Res. 25 Lett., n.d.

IPCC, 2013: The Physical Science Basis. Contribution of Working Group I to the Fifth Assessment Report of the Intergovernmental Panel on Climate Change, Cambridge University Press, Cambridge, United Kingdom and New York, NY, USA. [online] Available from: http://scholar.google.nl/scholar?hl=nl\&q=climate+change\&btnG=\&lr=\&oq=climate+ca\#2, 2013.

Kripalani, R. H., Oh, J. H., Kulkarni, A., Sabade, S. S. and Chaudhari, H. S.: South Asian summer monsoon precipitation 30 variability: Coupled climate model simulations and projections under IPCC AR4, Theor. Appl. Climatol., 90(3-4), 133-159, doi:10.1007/s00704-006-0282-0, 2007.

Kumar, D., Arya, D. S., Murumkar, A. R. and Rahman, M. M.: Impact of climate change on rainfall in Northwestern Bangladesh using multi-GCM ensembles, Int. J. Climatol., 34(5), 1395-1404, doi:10.1002/joc.3770, 2014.

Kumar, K. K., Kamala, K., Rajagopalan, B., Hoerling, M. P., Eischeid, J. K., Patwardhan, S. K., Srinivasan, G., Goswami, B. N. and Nemani, R.: The once and future pulse of Indian monsoonal climate, Clim. Dyn., 36(11-12), 2159-2170, doi:10.1007/s00382-010-0974-0, 2011.

Lau, W. K. M. and Kim, K. M.: Fingerprinting the impacts of aerosols on long-term trends of the Indian summer monsoon regional rainfall, Geophys. Res. Lett., 37(16), n/a-n/a, doi:10.1029/2010GL043255, 2010. 
Lee, D., Min, S.-K., Fischer, E. M., Shiogama, H., Bethke, I., Lierhammer, L. and Scinocca, J.: Impacts of half a degree additional warming on the Asian summer monsoon rainfall characteristics, Environ. Res. Lett., doi:10.1088/1748-9326/aab55d, 2018.

Li, Z., Lau, W. K. M., Ramanathan, V., Wu, G., Ding, Y., Manoj, M. G., Liu, J., Qian, Y., Li, J., Zhou, T., Fan, J., Rosenfeld, D., Ming, Y., Wang, Y., Huang, J., Wang, B., Xu, X., Lee, S. S., Cribb, M., Zhang, F., Yang, X., Zhao, C., Takemura, T., Wang, K.,

5 Xia, X., Yin, Y., Zhang, H., Guo, J., Zhai, P. M., Sugimoto, N., Babu, S. S. and Brasseur, G. P.: Aerosol and monsoon climate interactions over Asia, Rev. Geophys., 54(4), 866-929, doi:10.1002/2015RG000500, 2016.

Massey, N., Jones, R., Otto, F. E. L., Aina, T., Wilson, S., Murphy, J. M., Hassell, D., Yamazaki, Y. H. and Allen, M. R.: Weather@Home-Development and Validation of a Very Large Ensemble Modelling System for Probabilistic Event Attribution, Q. J. R. Meteorol. Soc., 141(690), 1528-1545, doi:10.1002/qj.2455, 2015.

10 Menon, A., Levermann, A., Schewe, J., Lehmann, J. and Frieler, K.: Consistent increase in Indian monsoon rainfall and its variability across CMIP-5 models, Earth Syst. Dyn. Discuss., 4(1), 1-24, doi:10.5194/esdd-4-1-2013, 2013.

Mitchell, D., James, R., Forster, P. M., Betts, R. A., Shiogama, H. and Allen, M.: Realizing the impacts of a $1.5^{\circ} \mathrm{C}$ warmer world, Nat. Clim. Chang., 12(8), 3-4, 2015.

Mitchell, D., AchutaRao, K., Allen, M., Bethke, I., Beyerle, U., Ciavarella, A., Forster, P. M., Fuglestvedt, J., Gillett, N., Haustein, K., Ingram, W., Iversen, T., Kharin, V., Klingaman, N., Massey, N., Fischer, E., Schleussner, C. F., Scinocca, J., Seland, Ø., Shiogama, H., Shuckburgh, E., Sparrow, S., Stone, D., Uhe, P., Wallom, D., Wehner, M. and Zaaboul, R.: Half a degree additional warming, prognosis and projected impacts (HAPPI): Background and experimental design, Geosci. Model Dev., 10(2), 571-583, doi:10.5194/gmd-10-571-2017, 2017.

Murshed, S. B., Islam, A. K. M. and Khan, M. S. A.: Impact of climate change on rainfall intensity in Bangladesh, Dhaka, Bangladesh. [online] Available from: http://teacher.buet.ac.bd/akmsaifulislam/reports/Heavy_Rainfall_report.pdf, 2011.

NAS: National Academies of Sciences, Engineering and Medicine. Attribution of Extreme Weather Events in the Context of Climate Change, 2016.

Nowreen, S., Murshed, S. B., Islam, A. K. M. S., Bhaskaran, B. and Hasan, M. A.: Changes of rainfall extremes around the haor basin areas of Bangladesh using multi-member ensemble RCM, Theor. Appl. Climatol., 119(1-2), 363-377, doi:10.1007/s00704014-1101-7, 2015.

Otto, F. E. L.: Attribution of Weather and Climate Events, Annu. Rev. Environ. Resour., 42(1), 627-646, doi:10.1146/annurevenviron, 2017.

Ramanathan, V., Chung, C., Kim, D., Bettge, T., Buja, L., Kiehl, J. T., Washington, W. M., Fu, Q., Sikka, D. R. and Wild, M.: Atmospheric brown clouds: Impacts on South Asian climate and hydrological cycle, Proc. Natl. Acad. Sci., 102(15), 5326-5333, doi:10.1073/pnas.0500656102, 2005.

Rawlani, A. K. and Sovacool, B. K.: Building responsiveness to climate change through community based adaptation in Bangladesh, Mitig. Adapt. Strateg. Glob. Chang., 16(8), 845-863, doi:10.1007/s11027-011-9298-6, 2011.

Rimi, R. H., Haustein, K., Barbour, E. J., Allen, M. R., Jones, R. G. and Sparrow, S. N.: Evaluation of a large ensemble regional climate modelling system for extreme weather events analysis over Bangladesh, Int. J. Climatol., n.d.

Samset, B. H., Sand, M., Smith, C. J., Bauer, S. E., Forster, P. M., Fuglestvedt, J. S., Osprey, S. and Schleussner, C. F.: Climate Impacts From a Removal of Anthropogenic Aerosol Emissions, Geophys. Res. Lett., 45(2), 1020-1029, doi:10.1002/2017GL076079, 2018.

Schleussner, C. F., Lissner, T. K., Fischer, E. M., Wohland, J., Perrette, M., Golly, A., Rogelj, J., Childers, K., Schewe, J., Frieler, 
Hydrol. Earth Syst. Sci. Discuss., https://doi.org/10.5194/hess-2018-400

Manuscript under review for journal Hydrol. Earth Syst. Sci.

Discussion started: 10 September 2018

(C) Author(s) 2018. CC BY 4.0 License.
Hydrology and

Earth System

Sciences

Discussions

(c) (i)

K., Mengel, M., Hare, W. and Schaeffer, M.: Differential climate impacts for policy-relevant limits to global warming: The case of $1.5^{\circ} \mathrm{c}$ and $2{ }^{\circ} \mathrm{c}$, Earth Syst. Dyn., 7(2), 327-351, doi:10.5194/esd-7-327-2016, 2016.

Srivastava, A., Naresh Kumar, S. and Aggarwal, P. K.: Assessment on vulnerability of sorghum to climate change in India, Agric. Ecosyst. Environ., 138(3-4), 160-169, doi:10.1016/j.agee.2010.04.012, 2010.

5 Stainforth, D. A., Aina, T., Christensen, C., Collins, M., Faull, N., Frame, D. J., Kettleborough, J. A., Knight, S., Martin, A., Murphy, J. M., Piani, C., Sexton, D., Smith, L. A., Splcer, R. A., Thorpe, A. J. and Allen, M. R.: Uncertainty in predictions of the climate response to rising levels of greenhouse gases, Nature, 433(7024), 403-406, doi:10.1038/nature03301, 2005.

Stark, J. D., Donlon, C. J., Martin, M. J. and McCulloch, M. E.: OSTIA: An Operational, high resolution, real time, global sea surface temperature analysis system., in Oceans 2007 - Marine Challenges: Coastline to Deep Sea, pp. 1-4, IEEE., 2007.

10 Stott, P. A., Stone, D. A. and Allen, M. R.: Human Contribution to the Heat wave of 2003, Nature, 432(7017), 610-614, 2004.

The World Bank: Turn Down Heat: Why a 4 degree warmer world must be avoided. A Report for the World Bank by the Potsdam Institute for Climate Impact Research and Climate Analytics, Washington, DC: World Bank. [online] Available from: http://climatechange.worldbank.org/sites/default/files/Turn_Down_the_heat_Why_a_4_degree_centrigrade_warmer_world_must_ be_avoided.pdf, 2012.

15 Turner, A. G. and Annamalai, H.: Climate change and the South Asian summer monsoon, Nat. Clim. Chang., 2(8), 587-595, doi:10.1038/NCLIMATE1495, 2012.

van Vuuren, D. P., Edmonds, J., Kainuma, M., Riahi, K., Thomson, A., Hibbard, K., Hurtt, G. C., Kram, T., Krey, V., Lamarque, J. F., Masui, T., Meinshausen, M., Nakicenovic, N., Smith, S. J. and Rose, S. K.: The representative concentration pathways: An overview, Clim. Change, 109(1), 5-31, doi:10.1007/s10584-011-0148-z, 2011.

20 Wang, B., Liu, J., Yim, P. J. W. S. and Kiefer, T.: Recent change of the global monsoon precipitation ( 1979 - 2008 ), Clim. Dyn., 39(5), 1123-1135, doi:10.1007/s00382-011-1266-z, 2012.

Yatagai, A., Kamiguchi, K., Arakawa, O., Hamada, A., Yasutomi, N. and Kitoh, A.: Aphrodite constructing a long-term daily gridded precipitation dataset for Asia based on a dense network of rain gauges, Bull. Am. Meteorol. Soc., 93(9), 1401-1415, doi:10.1175/BAMS-D-11-00122.1, 2012. 
Hydrol. Earth Syst. Sci. Discuss., https://doi.org/10.5194/hess-2018-400

Manuscript under review for journal Hydrol. Earth Syst. Sci.

Discussion started: 10 September 2018

(c) Author(s) 2018. CC BY 4.0 License.

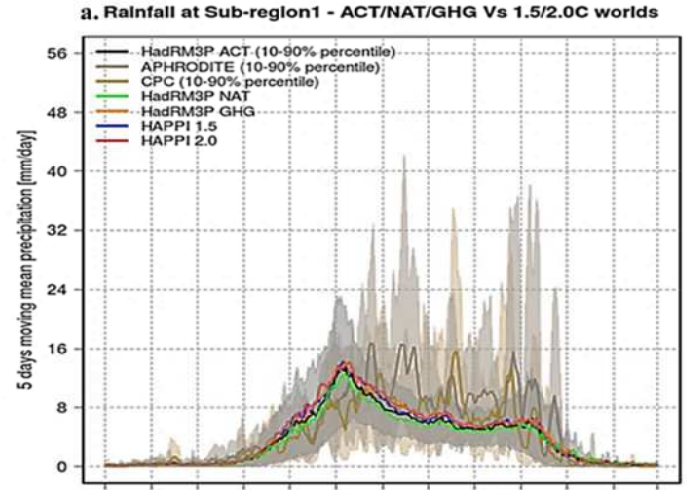

Jan Feb Mar Apr May Jun Jul Aug Sep Oct Nov Dec

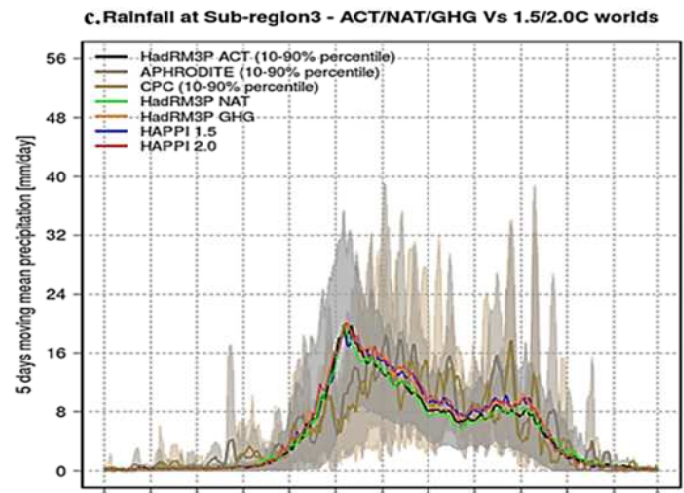

Jan Feb Mar Apr May Jun Jul Aug Sep Oct Nov Dec b. Ralnfall at Sub-reglon2 - ACT/NAT/GHG Vs 1.5/2.0C worlds

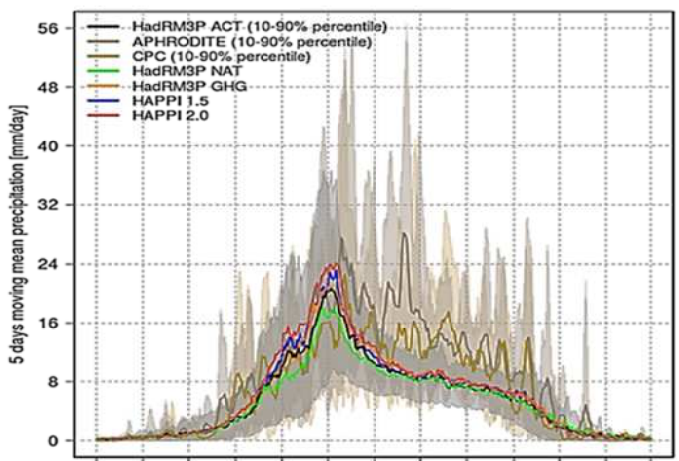

Jan Feb Mar Apr May Jun Jul Aug Sep Oct Nov Dec

d. Rainfall at Sub-reglon4 - ACT/NAT/GHG Vs $1.5 / 2.0 \mathrm{C}$ worlds

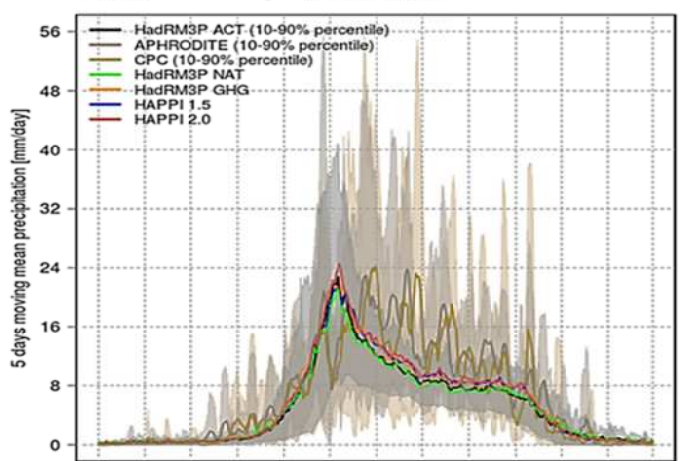

Jan Feb Mar Apr May Jun Jul Aug Sep Oct Nov Dec

Figure 1. Annual cycles of five day mean rainfall in different forcing scenarios over the four sub-regions of Bangladesh. The HadRM3P ACT (black), NAT (green) and GHG (orange), and HAPPI 1.5 (blue) and 2.0 (redl) ensembles are comparred with the observations from

10 APHRODITE (dark grey) and CPC (brown). The model can represent the annual cycles as in the observations but monsoon (JJAS) rainfall is underestimated in all sub-regions. A clearly distinguishable shift in the annual cycles of five day mean rainfall from NAT to ACT, from ACT to GHG, from ACT to HAPPI 1.5 and from HAPPI 1.5 to 2.0 foricing scenarios can be seen in sub-region2 only. 
Hydrol. Earth Syst. Sci. Discuss., https://doi.org/10.5194/hess-2018-400

Manuscript under review for journal Hydrol. Earth Syst. Sci.

Discussion started: 10 September 2018

(c) Author(s) 2018. CC BY 4.0 License.
Hydrology and

Earth System

Sciences

Discussions

(c) (i)

a. Pre-industrial to present

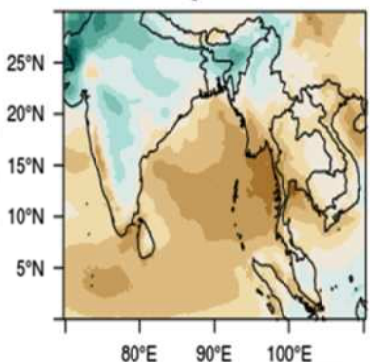

$80^{\circ} \mathrm{E} \quad 90^{\circ} \mathrm{E} \quad 100^{\circ} \mathrm{E}$

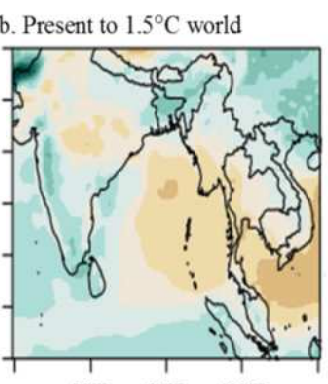

$80^{\circ} \mathrm{E} \quad 90^{\circ} \mathrm{E} \quad 100^{\circ} \mathrm{E}$

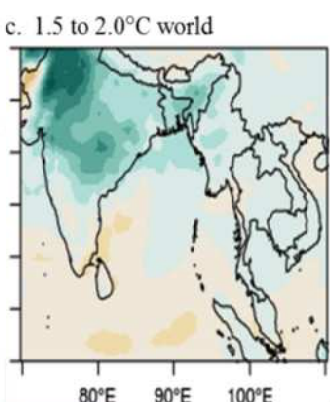

$80^{\circ} \mathrm{E} \quad 90^{\circ} \mathrm{E} \quad 100^{\circ} \mathrm{E}$ d. Aerosol reduction only

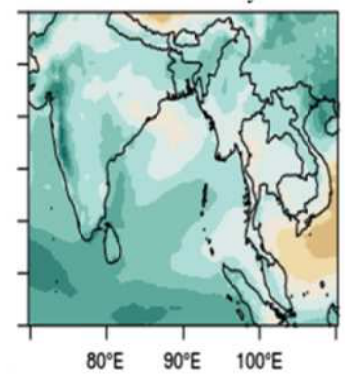

$\begin{array}{ccccccccc}-40 & -30 & -20 & -10 & 0 & 10 & 20 & 30 & 40\end{array}$

percent change (\%)
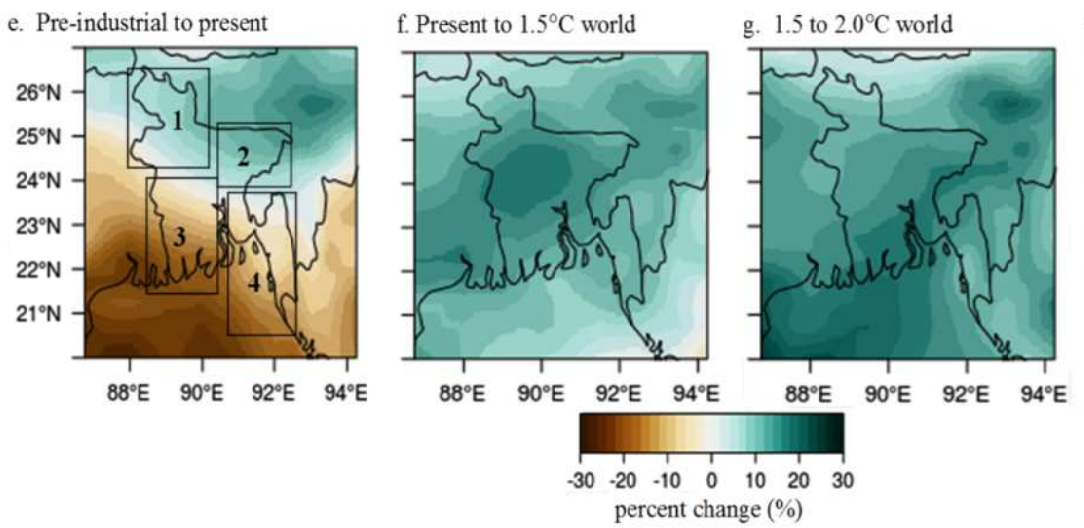

h. Aerosol reduction only

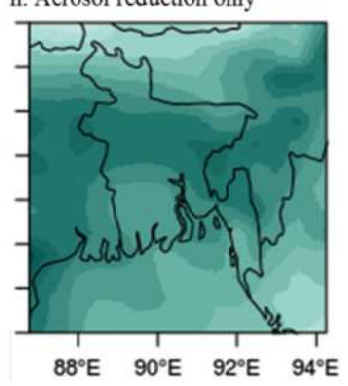

percent change $(\%)$

Figure 2. Percentage change (PC) in the pre-monsoon (MAM) seasonal mean rainfall between different fiorcing scenarios. The top row (panels a-d) shows the regional PC over central parts of the South Asia (SA) while, bottom row (panels e-h) shows the PC over

Bangladesh. The four boxes (1-4) on top of the panel e approximately represent the four sub-regions of Bangladesh. These four subregions 1-4 are used later for the relative quantification of risks of extreme pre-monsoon rainfall events. a. present day rainfall $\mathrm{PC}$ relative to natural pre-industrial climate over $\mathrm{SA}$ b. present day rainfall $\mathrm{PC}$ relative to $1.5^{\circ} \mathrm{C}$ world over $\mathrm{SA}$ c. $1.5^{\circ} \mathrm{C}$ world rainfall $\mathrm{PC}$ relative to $2.0^{\circ} \mathrm{C}$ world over $\mathrm{SA}$ d. present day rainfall $\mathrm{PC}$ relative to GHG only climate over SA. 
Hydrol. Earth Syst. Sci. Discuss., https://doi.org/10.5194/hess-2018-400

Manuscript under review for journal Hydrol. Earth Syst. Sci.

Discussion started: 10 September 2018

(c) Author(s) 2018. CC BY 4.0 License.
Hydrology and

Earth System

Sciences

Discussions

(c) (i)

a. Pre-industrial to present

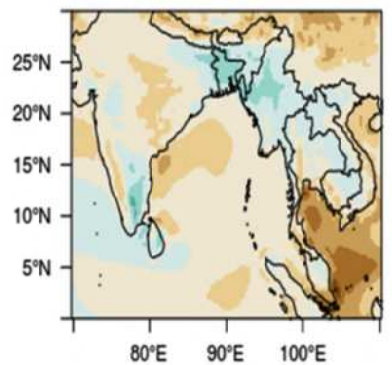

b. Present to $1.5^{\circ} \mathrm{C}$ world

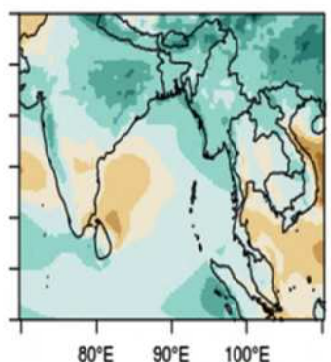

$\begin{array}{lllllll}-30 & -20 & -10 & 0 & 10 & 20 & 30\end{array}$

percent change $(\%)$

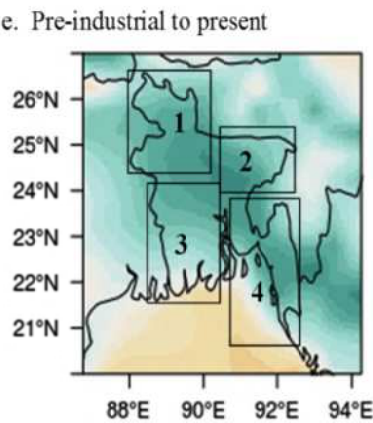

c. 1.5 to $2.0^{\circ} \mathrm{C}$ world

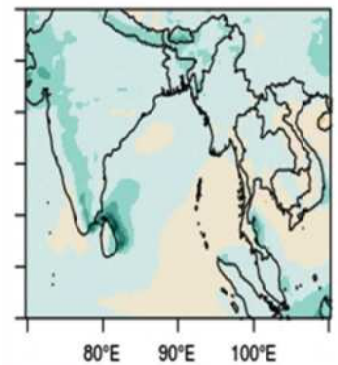

d. Aerosol reduction only

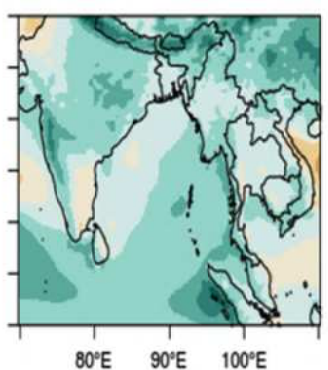

${ }^{8} 0^{\circ} \mathrm{E} \quad 90^{\circ} \mathrm{E} \quad 100^{\circ} \mathrm{E}$

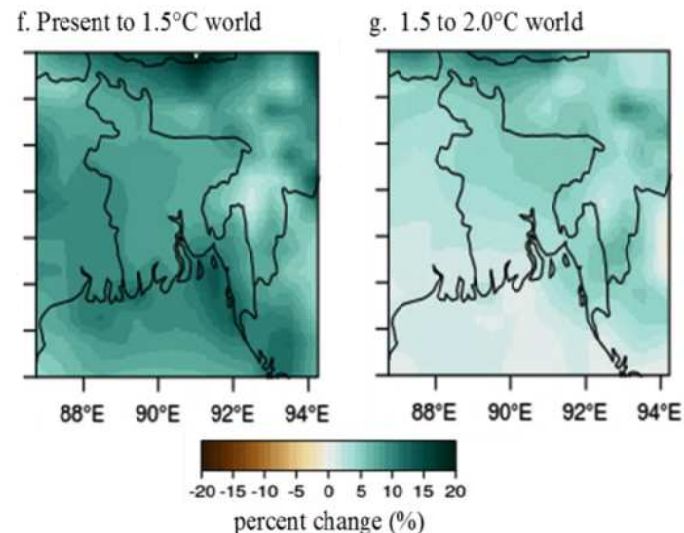

h. Aerosol reduction only

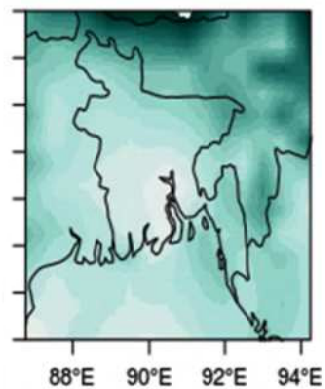

percent change $(\%)$

Figure 3. Percentage change (PC) in the monsoon (JJAS) seasonal mean rainfall between different forcing scenarios. The top row (panels a-d) shows the regional PC over central parts of the South Asia (SA) while, bottom row (panels e-h) shows the PC over Bangladesh. The four boxes (1-4) on top of the panel e approximately represent the four sub-regions of Bangladesh. These four subregions 1-4 are used later for the relative quantification of risks of extreme monsoon rainfall events. a. present day rainfall $\mathrm{PC}$ relative to natural pre-industrial climate over $\mathrm{SA}$ b. present day rainfall $\mathrm{PC}$ relative to $1.5^{\circ} \mathrm{C}$ world over $\mathrm{SA} \mathrm{c} .1 .5^{\circ} \mathrm{C}$ world rainfall $\mathrm{PC}$ relative to $2.0^{\circ} \mathrm{C}$ world over SA d. present day rainfall PC relative to GHG only climate over SA. The figure shows that the apparently non- 
Hydrol. Earth Syst. Sci. Discuss., https://doi.org/10.5194/hess-2018-400

Manuscript under review for journal Hydrol. Earth Syst. Sci.

Discussion started: 10 September 2018

(c) Author(s) 2018. CC BY 4.0 License.
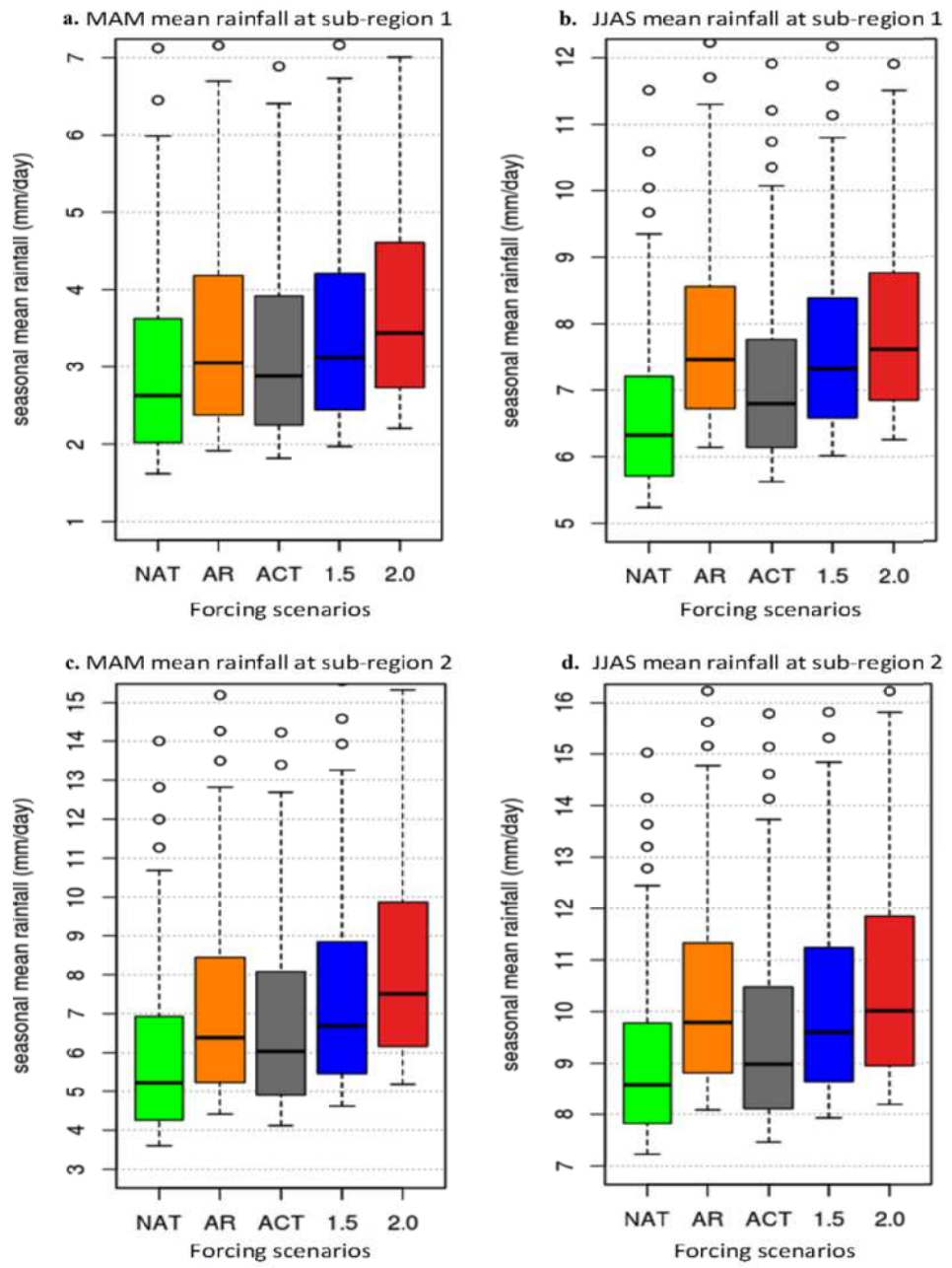

Figure 4. Mean rainfall in pre-monsoon (left column) and monsoon (right column) seasons during MAM and JJAS months over the subregions of 1 (top row) and 2 (bottom row) of Bangladesh. Green, orange, grey, blue and red colours represent the natural (NAT), actual climate with aerosols reduced to the pre-industrial level (AR), Actual (ACT), HAPPI 1.5 (1.5) and HAPPI 2.0 (2.0) ensembles respectively. Each panel has different $y$-scale range to clearly indicate the details of changes in the median values between different model ensembles. The horizontal black line in each box indicates the median value, the bottom and top limits of the box represents the $25^{\text {th }}$ and $75^{\text {th }}$ percentiles respectively. The figure shows that aerosol impacts are distinguishable between the dry sub-region 1 and the wet sub-region 2 . There is noticeable masking effect of aerosols that repress the change between NAT and ACT worlds at sub-region 1. In contrast, at sub-region 2, where highest amounts of observed rainfall can clear most of the pollution from the atmosphere, the masking effect in minimal hence, a robust change between NAT and ACT worlds can be seen. In future with additional warming the mean seasonal rainfall increases over both sub-regions but then again over the sub-region 2 , we see larger changes in the seasonal mean rainfall. 
Hydrol. Earth Syst. Sci. Discuss., https://doi.org/10.5194/hess-2018-400

Manuscript under review for journal Hydrol. Earth Syst. Sci.

Discussion started: 10 September 2018

(c) Author(s) 2018. CC BY 4.0 License.
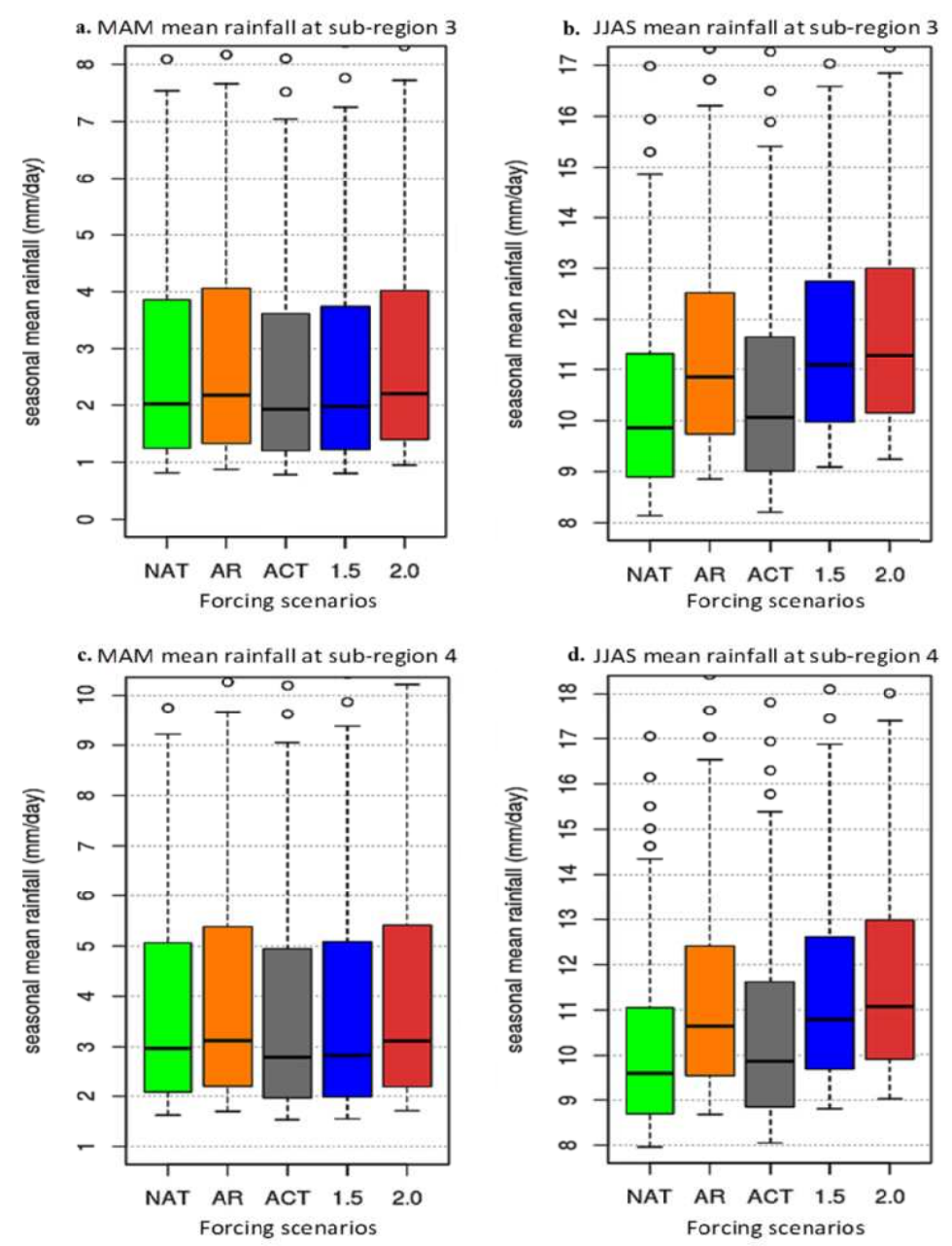

Figure 5. Mean rainfall in pre-monsoon (left column) and monsoon (right column)) seasons during MAM amd JJAS months over the subregions of 3 (top row) and 4 (bottom row) of Bangladesh. Green, orange, grey, blue and red colours represent the natural (NAT), actual climate with aerosols reduced to the pre-industrial level (AR), Actual (ACT), HAPPI 1.5 (1.5) and HAPPI 2.0 (2.0) ensembles respectively. Each panel has different $y$-scale range to clearly indicate the details of changes in the median values between different model ensembles. The horizontal black line in each box indicates the median value, the bottom and top limits of the box repre sents the 25th and 75th percentiles respectively. The aerosol impacts are distinguishable bettween the pre-monsoon and monsoon seasons. There is noticeable masking effect of aerosols that repress the change between NAT and ACT worlds at both sub-region 3 and 4 during premonsoon season. On the contrary, in monsoon season, large amounts of rainfall can clear most of the pollution from the atmosphere; so, the masking effect is minimal, hence, a clear change between NAT and ACT worlds is happening. In future with additional warming the mean seasonal rainfall increases over both sub-regions but, larger changes occur in the mean rainfall in monsoon season. 
Hydrol. Earth Syst. Sci. Discuss., https://doi.org/10.5194/hess-2018-400

Manuscript under review for journal Hydrol. Earth Syst. Sci.

Discussion started: 10 September 2018

(c) Author(s) 2018. CC BY 4.0 License.
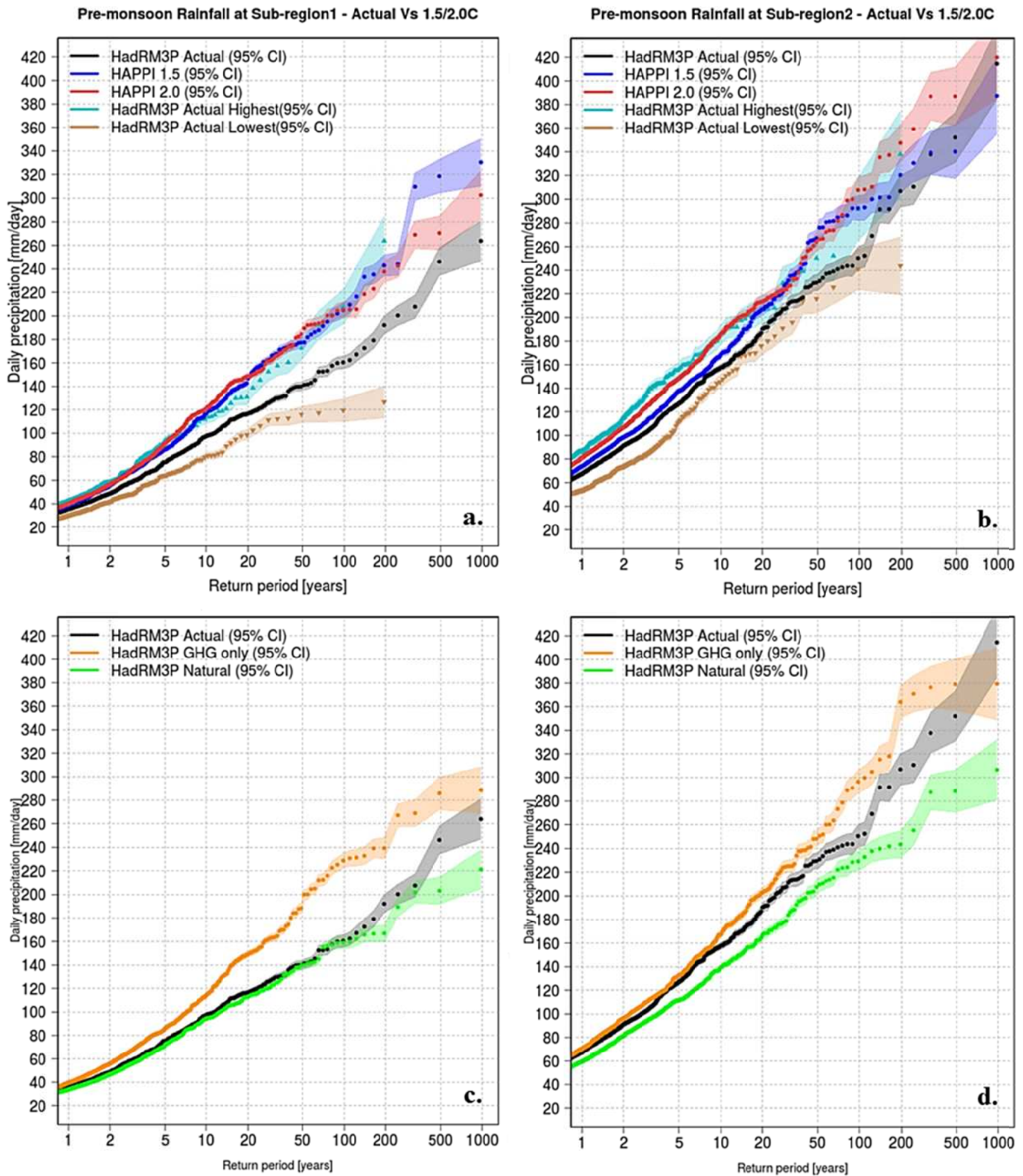

Figure 6. Return time plots for daily rainfall during pre-monsoon (MAM) season in different forcing scenarios over the sub-regions of 1 and 2 of Bangladesh. The HadRM3P ACT (black), ACT highest (upper grey with upward triangles), ACT lowest (lower grey' with downward triangles), NAT (green) and GHG (orange) ensembles are compared with the HAPPI 1.5 (bilue) ard 2.0 (red) ensembles.

10 Anthropogenic warming effects have not strongly influenced the present-day risks of extreme pre-monsoon rainfall in the sub-region1. With a 1.5 or 2.0 degrees' world, this sub-region might see extreme rainfall events with four-fold higher risks. 
Hydrol. Earth Syst. Sci. Discuss., https://doi.org/10.5194/hess-2018-400

Manuscript under review for journal Hydrol. Earth Syst. Sci.

Discussion started: 10 September 2018

Hydrology and

(c) Author(s) 2018. CC BY 4.0 License.
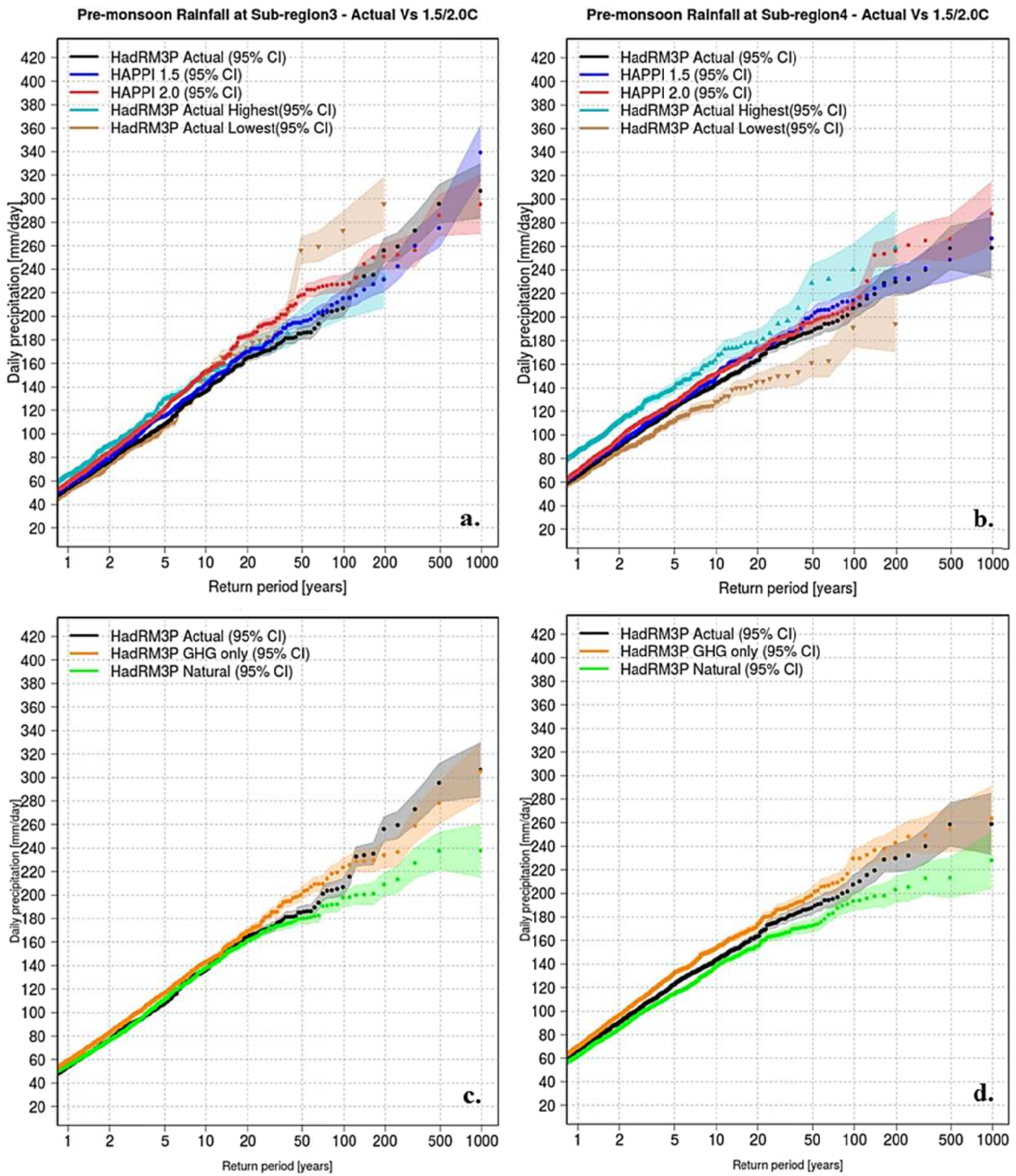

Figure 7. Same as Fig 6, but showing return time plots for daily rainfall during pre-monsoon (MAM) season in different forcing 
Hydrol. Earth Syst. Sci. Discuss., https://doi.org/10.5194/hess-2018-400

Manuscript under review for journal Hydrol. Earth Syst. Sci.

Discussion started: 10 September 2018

(c) Author(s) 2018. CC BY 4.0 License.

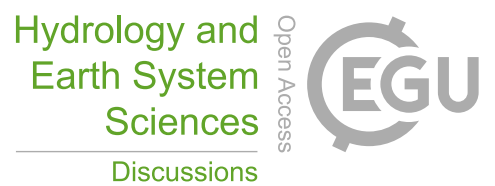

(c) (1)
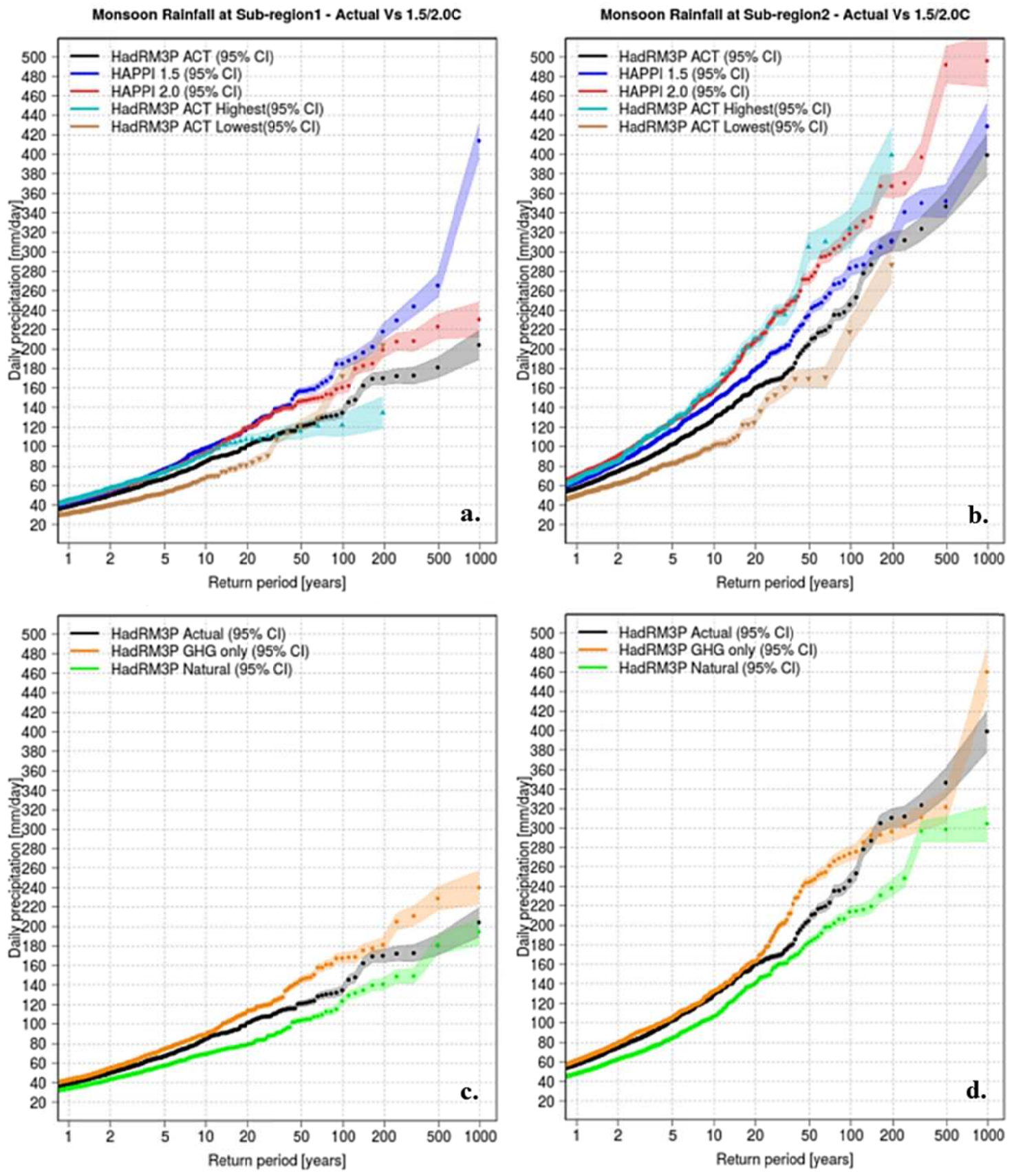

Figure 8. Return time plots for daily rainfall during monsoon (JJAS) season in different forcing scen arios over the sub-regions of 1 and 2 of Bangladesh. The HadRM3P ACT (black), ACT highest (upper grey with upward triangles), ACT lowest (lower grey with

10 downward triangles), NAT (green) and GHG (orange) ensembles are compared with the HAPPI 1.5 (blue)) and 2.0 (red) ensembles. The most significant changes in the risks of extreme monsoon rainfall take place in the sub-region2, which is already the wettest part of Bangladesh. 
Hydrol. Earth Syst. Sci. Discuss., https://doi.org/10.5194/hess-2018-400

Manuscript under review for journal Hydrol. Earth Syst. Sci.

Discussion started: 10 September 2018

(c) Author(s) 2018. CC BY 4.0 License.
Hydrology and Earth System Sciences

Discussions (c) (i)
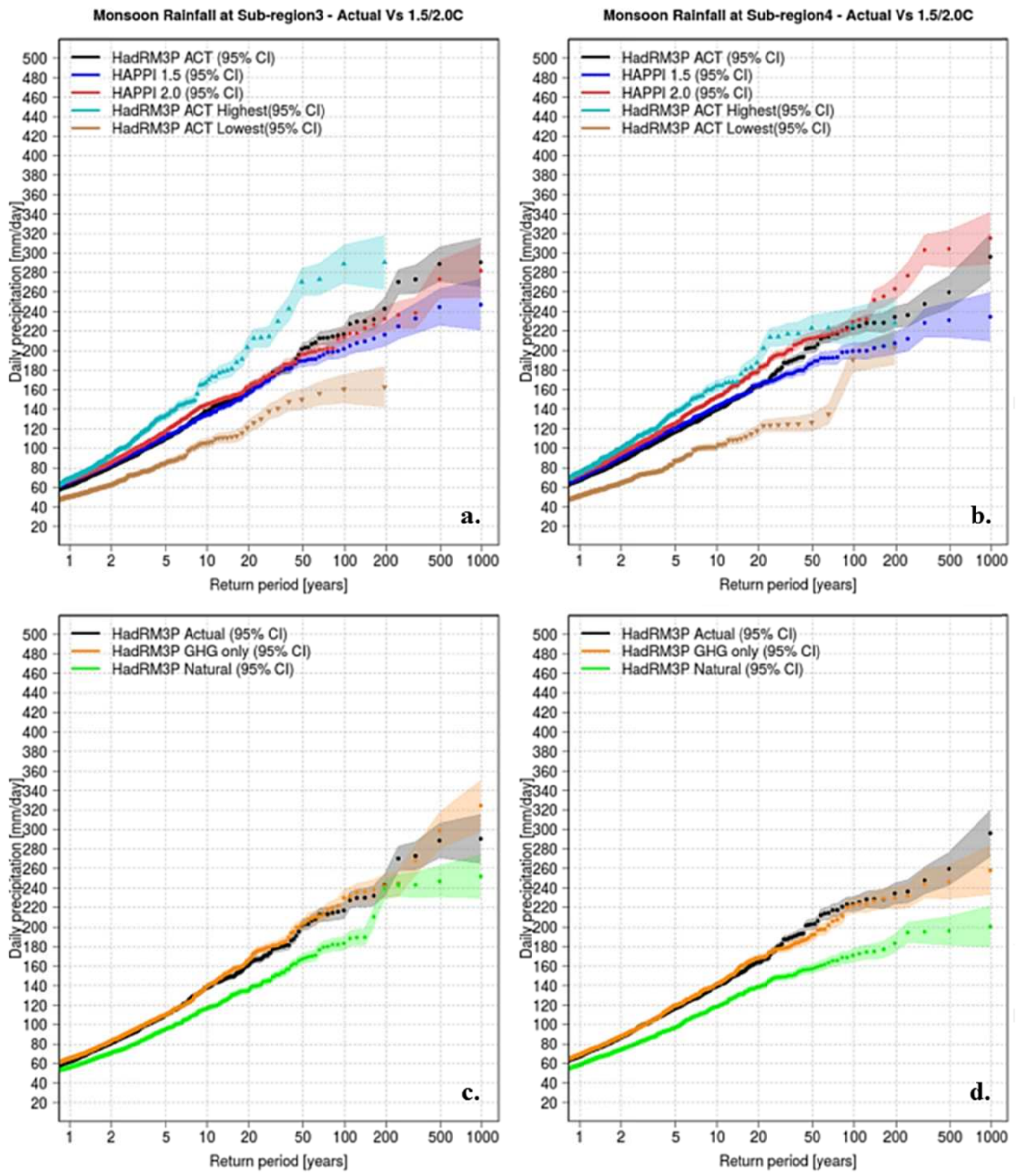

5 Figure 9. Same as Fig 8, but showing return time plots for daily rainfall during monsoon (JJAS) season in different forcing scemarios over the sub-regions of 3 and 4 of Bangladesh. 
Hydrol. Earth Syst. Sci. Discuss., https://doi.org/10.5194/hess-2018-400

Manuscript under review for journal Hydrol. Earth Syst. Sci.

Discussion started: 10 September 2018

(C) Author(s) 2018. CC BY 4.0 License.
Hydrology and

Earth System

Sciences

Discussions

(c) (i)

a. Risk Ratio of MAM rainfall events over sub-region 1

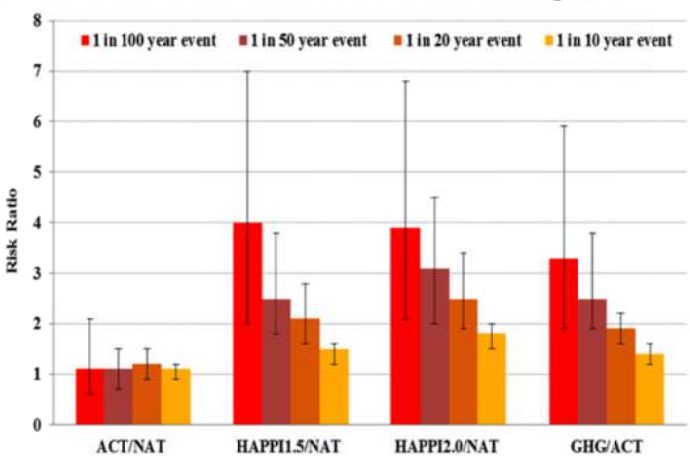

c. Risk Ratio of JJAS rainfall events over sub-region 1

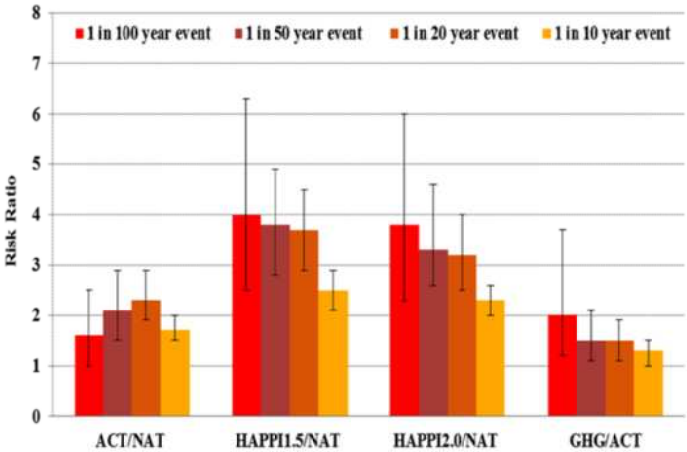

b. Risk Ratio of MAM rainfall events over sub-region 2

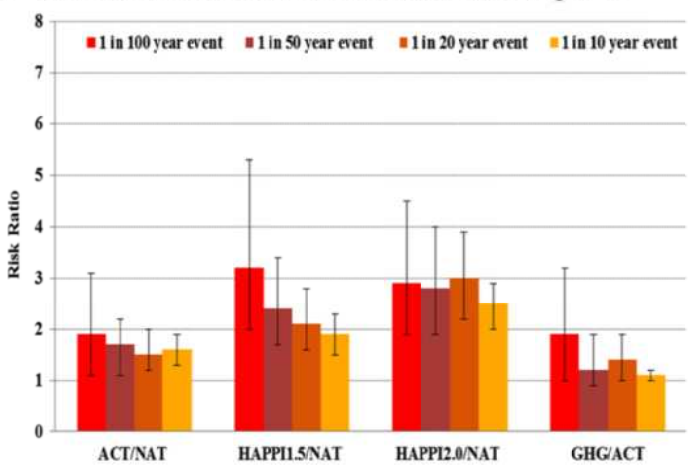

d. Risk Ratio of JJAS rainfall events over sub-region 2

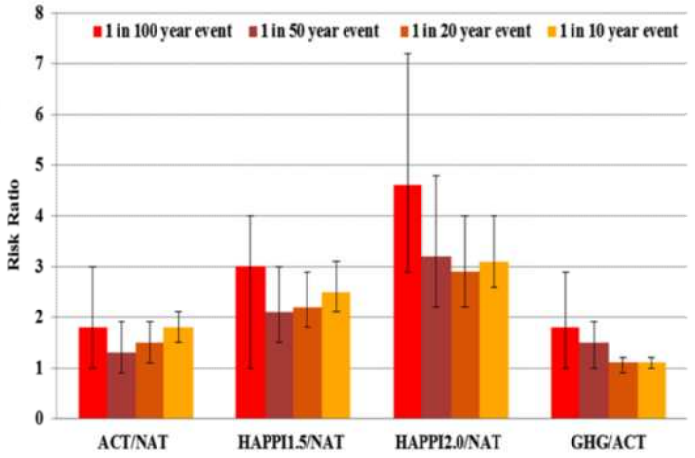

10 Figure 10. The risk ratios of four specific rainfall events with return periods of 10, 20, 50, and100 years between Actual/Natural, HAPPI 1.5/Natural, HAPPI 2.0/Natural and GHG/Actual over the two northern sub-regions of 1 and 2 of Bangladesh in pre-monsoon (MAM) (shown in top two panels of a. and b.) and monsoon (JJAS) (shown in bottom two panels of c. and d.) seasons. The error bars indicate the associated uncertainty range with $95 \%$ confidence level for individual event.. This figure demonstrattes that the uncertaint y range increases with the increase of the return periods of rainfall events (i.e., rarer events) in most of the cases, which should be considered in the risk assessment process. While there is no discernible climate change impacts on the current risks (i.e.,, all four risk ratios are $\sim 1$ ), in $a^{1} .5^{\circ} \mathrm{C}$ world there would be 4 (with uncertainty range 2.0-7.0) times increase in the risks of extreme rainfall events of 100 years return period over sub-region 1 during pre-monsoon season (top-left panel a.). 
Hydrol. Earth Syst. Sci. Discuss., https://doi.org/10.5194/hess-2018-400

Manuscript under review for journal Hydrol. Earth Syst. Sci.

Discussion started: 10 September 2018

(C) Author(s) 2018. CC BY 4.0 License.
Hydrology and

Earth System

Sciences

Discussions

(c) (i)

a. Risk Ratio of MAM rainfall events over sub-region 3

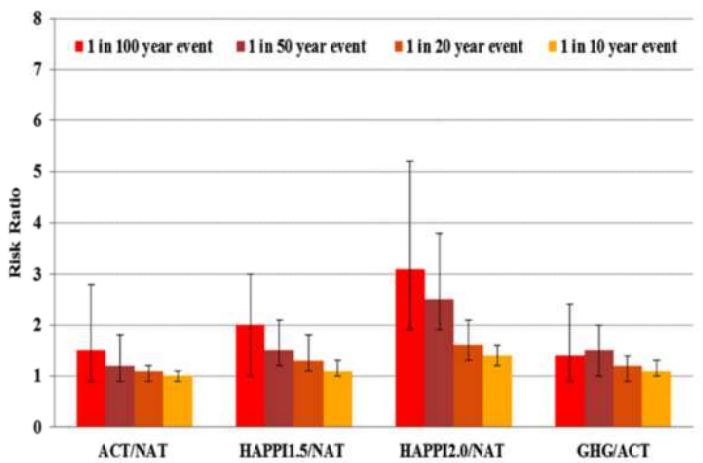

c. Risk Ratio of JJAS rainfall events over sub-region 3

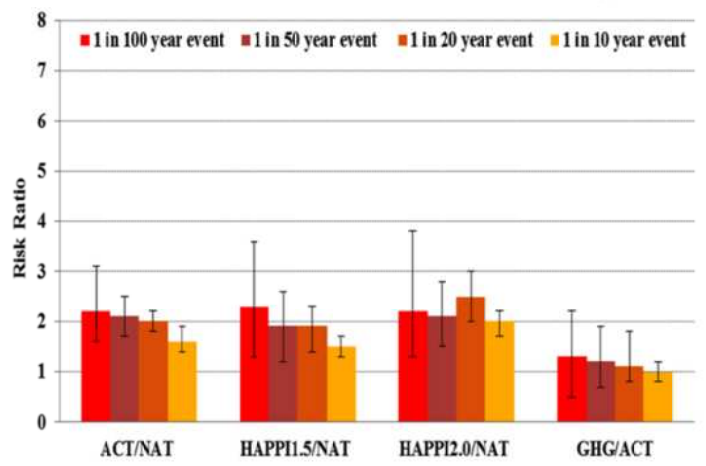

b. Risk Ratio of MAM rainfall events over sub-region 4

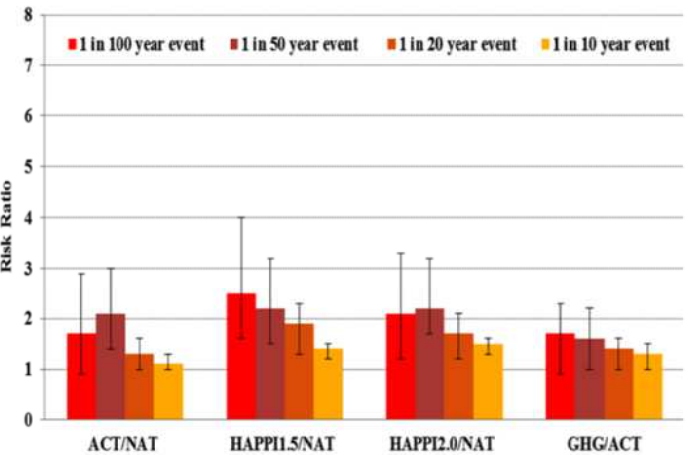

d. Risk Ratio of JJAS rainfall events over sub-region 4

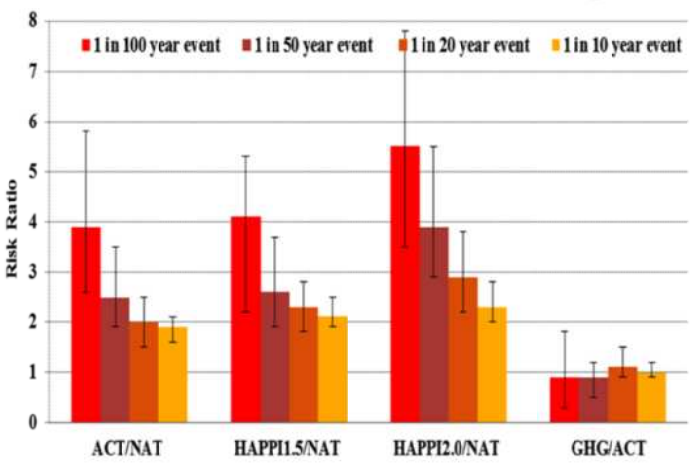

Figure 11. The risk ratios of four specific rainfall events with return periods of 10, 20, 50, and100 years between Actual/Natural, HAPPI

1.5/Natural, HAPPI 2.0/Natural and GHG/Actual over the two southern sub-regions of 3 and 4 of Bangladesh in pre-monsoon (MAM) (shown in top two panels of a. and b.) and monsoon (JJAS) (shown in bottom two panels of $c$. and d.) seasons. The error bars indicate the associated uncertainty range with $95 \%$ confidence level for individual event. The risk ratios over sub-region 4 in monsoon (bottom right panel d.) indicate that the extreme rainfall events with 100 years return period are already made 3.9 (with uncertainty range 2.65.8) times likely in the actual climate compared to the evients of natural climate. With additional global warming effects the same event will become 4.1 (with uncertainty range $2.2-5.3$ ) and 5.5 (with uncertainty range 3.5-7.8) times likely in a 1.5 and 2.0 degrees' worlds. 